\title{
International Transmission of Bank and Corporate Distress
}

\author{
Qianying Chen, Dale Gray, \\ Papa N'Diaye, Hiroko Oura, and \\ Natalia Tamirisa
}




\title{
IMF Working Paper
}

\author{
Research Department
}

International Transmission of Bank and Corporate Distress

\section{Prepared by Qianying Chen, Dale Gray, Papa N'Diaye, Hiroko Oura, and Natalia Tamirisa ${ }^{1}$}

\author{
Authorized for distribution by Jonathan D. Ostry
}

May 2010

\begin{abstract}
This Working Paper should not be reported as representing the views of the IMF. The views expressed in this Working Paper are those of the author(s) and do not necessarily represent those of the IMF or IMF policy. Working Papers describe research in progress by the author(s) and are published to elicit comments and to further debate.

The paper evaluates how increases in banks' and nonfinancial corporates' default risk are transmitted in the global economy, using in a vector autoregression model for 30 advanced and emerging economies for the period from January 1996 to December 2008. The results point to two-way causality between bank and corporate distress and to significant global macroeconomic and financial spillovers from either type of distress when it originates in a systemic economy. Corporate distress in advanced economies has a larger impact on economic growth in emerging economies than bank distress in advanced economies has. In contrast, activity in advanced economies is more vulnerable to bank distress than to corporate distress.

JEL Classification Numbers: F41, F47, G15, G20, G30, C51

Keywords: bank, corporate, distress, GVAR, financial, international, spillovers

Authors’ E-Mail Addresses: qichen@,wiwi.uni-frankfurt.de, pndiaye@,imf.org, dgray@imf.org, houra@,imf.org,ntamirisa@imf.org
\end{abstract}

\footnotetext{
${ }^{1}$ The authors are grateful to Joshua Felman and Jonathan D. Ostry for encouragement and support. Philip Lane kindly shared data on external financial exposures and Xuan Zhang provided the Matlab code for model estimation. The authors thank Andy Berg, Claudia Buch, Stijn Claessens, Jean Imbs, and other participants in the ECB/Bundesbank Workshop on Global Interdependence and the IMF Research Department's seminar for insightful and helpful comments and Ryan Scuzzarella and Jair Rodriquez for excellent research assistance. Qianying Chen is a Ph.D. student at the Goethe University in Frankfurt and currently an economist at the Hong Kong Institute for Monetary Research.
} 
Contents

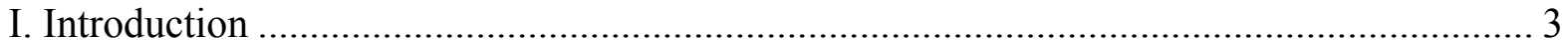

II. Methodology and Data ........................................................................................ 4

A. Structure of the GVAR Model ............................................................................. 4

B. Sample, Variables, and Weights ........................................................................ 7

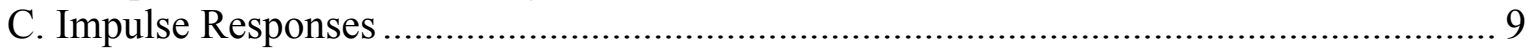

III. Transmission of Bank and Corporate Distress........................................................ 10

A. Domestic Impact of Bank and Corporate Distress ............................................... 10

B. International Propagation of Bank and Corporate Distress...................................... 11

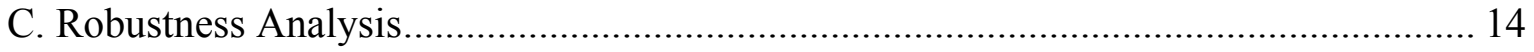

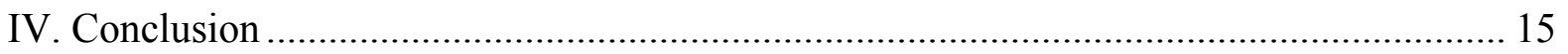

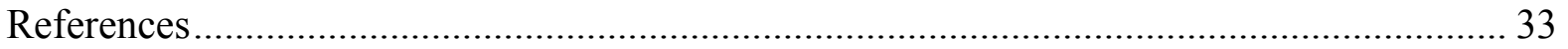

Appendix I. Data Description .................................................................................. 35

Appendix II. Contingent Claims Analysis and Estimating Default Probabilities for Corporate and Banks 


\section{INTRODUCTION}

The recent crisis demonstrated how rapidly financial distress can be transmitted to the domestic economy and across borders. The U.S. subprime crisis weakened balance sheets of banks, households and corporates put major financial institutions in that economy and other advanced economies on the brink of bankruptcy, were it not for large government bailouts. The subsequent tightening of global financial conditions, together with the seizure of capital markets, reduced the availability of funding for nonfinancial corporations around the world, hampering their capacity to produce, export and invest. Households (and consumption) in advanced economies were also hit: many individuals lost their jobs and experienced large declines in net worth. Confidence fell around the world, and with it, activity.

Credit has played a key role in the transmission of financial distress to the broader economy, consistent with evidence from the literature. Indeed, studies by Gilchrist et al (2009), Marcucci and Quagliariello (2008), Jacobson et al, 2005, and Carlson et al (2008) show that the credit channel is the main channel of transmission of financial distress, the strength of which hinges on that of the financial accelerator - the extent to which borrowing costs depend on the external finance premium that reflects borrowers' net worth (Bernanke and Gertler, 1995; Bernanke, Gertler and Gilchrist, 1999; and Kiyotaki and Moore, 1997). In this process, the health of banks' balance sheets, particularly the size of their capital, have a bearing on the amount of credit banks provide - the so-called bank capital channel (Bernanke, Lown, and Friedman, 1991; and Kashyap and Stein, 1995). At the same time, banks' ability to increase leverage plays a similar role (Adrian and Shin, 2008; and Berger and Bouwman, 2008).

The evidence on the transmission of financial distress has mostly been limited to advanced economies and seldom uses a framework that integrates macroeconomic, financial and (nonfinancial) corporate sector variables. For example, recent papers on credit risk (Carlson et al, 2008; and Pesaran et al, 2004) examined the spillover effects of credit risk shocks in a multi-country context, using a global vector autoregression model (Dees et al, 2007), but with the credit risk modeled separately from macroeconomic variables. Financial distress in these papers is measured as bank capital or borrowers' default risk, proxied by corporate bond spreads, credit default swap spreads or data on actual defaults. These data are available only for a limited number of (mostly advanced) economies, which limits the scope of analysis.

This paper attempts to fill the void in the literature by providing an integrated analysis of the linkages between bank and (nonfinancial) corporate sectors in the global economy. It does so by introducing forward-looking measures of default risk for banks and corporates into a Global Vector Autoregression (GVAR) model proposed by Pesaran, Schuermann, and Weiner (2004). Bank and corporate default risk is proxied by the respective Expected Default Frequencies (EDFs) from Moody's KMV Credit Edge. The EDF uses information on a bank's or corporate's balance sheet and equity market data, and is often referred to as the equity market-implied default risk (Vassalou and Xing, 2004). The limited data requirements for calculating the EDFs mean that such measures can be created for a large number of financial and non-financial corporate firms across the world, including those from emerging markets, which is a great advantage for the analysis of international spillovers. In addition to 
the EDFs, the GVAR model includes macroeconomic variables, such as industrial production, real short-term interest rates, real effective exchange rates and real stock prices; oil prices are treated as a global factor.

Like the earlier studies, the study finds linkages between the financial sector and the real economy, with distress in the banking or corporate sector having significant effects on activity in domestic economies. In particular, the results show that bank distress amplifies corporate distress, reduces industrial production and stock prices, and tends to be accompanied by a depreciation of real effective exchange rates and lower real short-term interest rates. Corporate distress has broadly similar macroeconomic effects.

Bank and corporate distress are also found to have significant global repercussions, albeit with striking differences for advanced and emerging economies. International spillovers are stronger when financial distress originates in large advanced economies, particularly the United States. The impact of corporate distress originating in advanced economies on growth in emerging economies tends to be larger than the impact of advanced economies' bank distress, consistent with a more prominent role of trade channels in the transmission of advanced economies' shocks to emerging economies. In contrast, advanced economies tend to be more vulnerable to bank distress than corporate distress, reflecting the greater role of the financial sector in these economies.

These conclusions are qualitatively robust to a variety of changes in model specification, including alternative weights and ordering of variables. When bank and corporate default measures are excluded from the model, the effects of shocks are similar in direction but smaller in magnitude. Thus, bank and corporate balance sheet channels appear to be an important amplifier of the international transmission of shocks, consistent with the financial accelerator mechanism and findings by Dees et al (2007). The findings also appear broadly consistent with experiences during the recent financial crisis.

The rest of the paper is organized as follows. Section II presents the GVAR framework and describes the data, particularly Moody's KMV EDFs. Section III discusses the results of selected shocks. Section IV concludes.

\section{Methodology ANd DATA}

The GVAR model of Pesaran, Schuermann and Weiner (2004) provides a multilateral dynamic framework for the analysis of interdependence and international transmission of country-specific shocks among a large number of economies.

\section{A. Structure of the GVAR Model}

The structure of the GVAR model can be summarized as the follows. Consider $N+1$ economies, indexed by $i=0,1,2, \ldots, N$, and a vector $\mathbf{x}_{i t}$ of $k_{i}$ domestic variables for each economy. Stacking the vectors of country-specific variables, 


$$
\mathbf{x}_{t}=\left(\begin{array}{cccc}
\mathbf{x}_{0 t}^{\prime}, & \mathbf{x}_{1 t}^{\prime}, \quad \ldots, & \mathbf{x}_{N t}^{\prime}
\end{array}\right)
$$

a VAR in $\mathbf{x}_{t}$ would contain too many parameters to be estimated if the time dimension T of the data is not much larger than the number of economy N. Instead of regressing $\mathbf{x}_{i, t}$ on

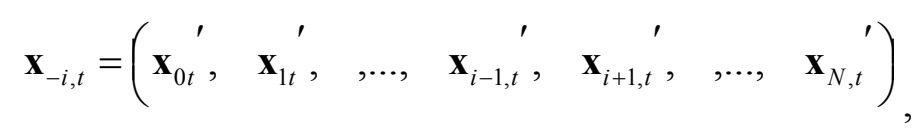

without any restriction, GVAR links $\mathbf{x}_{i, t}$ to a $k_{i}^{*} \times 1$ vector $\mathbf{x}_{i, t}^{*}$, where

$$
x_{\ell i t}^{*}=\sum_{j=0}^{N} \omega_{\ell i j} x_{\ell j t}, \quad \ell=1,2, \ldots, k_{i}^{*} .
$$

The weight $\omega_{l i j}$ captures the spillover effect of variable $l$ of foreign economy $j$ on variable $l$ of domestic economy $i$. Since $\omega_{l i j}$ measures the relative importance of economy $j$ to economy $i$, the spillover effect of variable $l$ is in proportion to the weight chosen to measure the relative importance. Therefore, each economy's component of GVAR is given as a $\operatorname{VARX} *\left(p_{i}, q_{i}\right)$ :

$$
\begin{aligned}
& \mathbf{x}_{i t}=\mathbf{a}_{i o}+\mathbf{a}_{i 1} \cdot t+\sum_{s=1}^{p_{i}} \boldsymbol{\Phi}_{i s} \mathbf{x}_{i, t-s}+\sum_{s=0}^{q_{i}} \boldsymbol{\Lambda}_{i s} \mathbf{x}_{i, t-s}^{*}+\sum_{s=0}^{r_{i}} \boldsymbol{\Psi}_{i s} \mathbf{d}_{t-s}+\mathbf{u}_{i t} \\
& \text { with } u_{i t}^{i i d} \sim\left(0, \sum_{i}\right)
\end{aligned}
$$

where $\mathbf{d}_{t-s}$ is the observed common factor of $q \times 1$ dimension and $\boldsymbol{\varepsilon}_{i t}$ is iid across time. Country-specific vector $\mathbf{x}_{i, t-s}^{*}$ reflects interdependence among economies and serves as a proxy for the unobserved common effects across economies. The country-specific foreign variables and common factors are treated as weakly exogenous (if confirmed by statistical tests), i.e., they are "long-run forcing" country-specific domestic variables. The term "longrun forcing" means that in the equations for foreign variables, the coefficients on the errorcorrection terms are set to zero. The dynamics of foreign variables are not influenced by deviations from the long-run equilibrium path, in contrast to the dynamics of domestic variables.

The VARX* can be estimated economy by economy using the ordinary least squares (OLS) method or rank-reduced approach if the cross-dependence of the idiosyncratic shock is sufficiently small, that is:

$$
\sum_{j=0}^{N} \operatorname{Cov}\left(\varepsilon_{\ell i t}, \varepsilon_{s j t}\right) / N \rightarrow 0
$$


all $i \neq j, l$ and $s$.

From equation (3), it can be seen that

$$
\mathbf{z}_{i t}=\mathbf{W}_{i} \mathbf{x}_{t} \quad i=1,2, \ldots, N
$$

Where $\mathbf{z}_{i t}=\left(\begin{array}{ll}\mathbf{x}_{i t}^{\prime} & \mathbf{x}_{i t}^{*^{\prime}}\end{array}\right)$ and $\mathbf{W}_{i}$ is an appropriately defined weighting scheme. Thus, stacking (4) across $i$, the endogenous variables can be solved for in a global system:

$$
\mathbf{G} \mathbf{x}_{t}=\mathbf{a}_{i 0}+\mathbf{a}_{i 1} \cdot t+\sum_{s=1}^{p} \boldsymbol{\Phi}_{s} \mathbf{x}_{t-s}+\sum_{s=0}^{r} \boldsymbol{\Psi}_{s} \mathbf{d}_{t-s}+\mathbf{u}_{t}
$$

thus

$$
\mathbf{x}_{t}=\mathbf{G}^{-\mathbf{1}} \mathbf{a}_{i 0}+\mathbf{G}^{-\mathbf{1}} \mathbf{a}_{i 1} \cdot t+\mathbf{G}^{-\mathbf{1}} \sum_{s=1}^{p} \boldsymbol{\Phi}_{s} \mathbf{x}_{t-s}+\mathbf{G}^{-\mathbf{1}} \sum_{s=0}^{r} \boldsymbol{\Psi}_{s} \mathbf{d}_{t-s}+\mathbf{G}^{-\mathbf{1}} \mathbf{u}_{t}
$$

Where $p=\max \left\{p_{i}, q_{i}\right\}, r=\max \left\{r_{i}\right\}$, and

$$
G=\left(\begin{array}{c}
A_{0} W_{0} \\
A_{1} W_{1} \\
\vdots \\
A_{N} W_{N}
\end{array}\right), \quad H_{s}=\left(\begin{array}{c}
B_{s, 0} W_{0} \\
B_{s, 1} W_{1} \\
\vdots \\
B_{s, N} W_{N}
\end{array}\right), u_{t}=\left(\begin{array}{c}
u_{0, t} \\
u_{1, t} \\
\vdots \\
u_{N, t}
\end{array}\right)
$$

Equation (8) is a VAR for the complete set of domestic variables for all economies.

The advantage of the GVAR model is that it makes the estimation of (8) feasible by accounting for interdependence among economies and then estimating the partial system on a economy-by-economy basis, which implies allowing for modeling a large number of economies. The impulse response is computed based on (8).

The vector for domestic variables is given by:

$$
\mathbf{x}_{i t}=\left(\begin{array}{llllll}
e d f b_{i t} & e d f n_{i t} & r_{i t} & y_{i t} & p_{i t}^{s} & q_{i t}
\end{array}\right)^{\prime}
$$

where $e d f b_{i t}$ denotes the logarithm of asset-weighted average expected default frequency (EDF) of banks and $e d f n_{i t}$ for (nonfinancial) corporates, $r_{i t}$ is the real money market rate, $y_{i t}$ is the logarithm of industrial production, $p_{i t}^{s}$ the logarithm of real share price index, and $q_{i t}$ is the logarithm of the real effective exchange rate. 
The vector for foreign variables for each economy except the United States is given by:

$$
\mathbf{x}^{*}{ }_{i t}=\left(\begin{array}{lllll}
e d f b_{i t}^{*} & e d f n_{i t}^{*} & r_{i t}^{*} & y_{i t}^{*} & p_{i t}^{s^{*}}
\end{array}\right)^{\prime}
$$

We do not construct foreign effective exchange rates to minimize the number of parameters to be estimated, since information about foreign economies' currency is captured in the (trade-weighted) real effective exchange rate $q_{i t}$.

The foreign variable for the United States is constructed as:

$$
\mathbf{x}^{*}{ }_{u s, t}=y^{*}{ }_{u s, t}
$$

Given the large influence of the U.S. financial variables on global markets, the U.S. foreign financial variables are less likely to be weakly exogenous for the U.S. domestic variables. That is the main reason we do not include the U.S. foreign financial variables in the equations for the United States.

The spot oil price is included as a common factor $d_{t-s}$ to remove the common component in the reduced form residuals. Another candidate for inclusion as a common factor could be the index of global stock price volatility VIX, to ensure that the EDF shocks are purely idiosyncratic. However, because the VIX is driven by volatility in U.S. share prices, it is not weakly exogenous to the U.S. variables. Adding it separately will not augment the information content of the model.

Equations (3) and (4) show that the spillover effect of a foreign variable on a domestic variable is proportional to the weight $\omega_{l i j}$, which measures the relative importance of economy $i$ to economy $j$ in transmission. Since the transmission channels for financial variables are likely to be different from the transmission channels for the variables measuring real activity, we use financial weights to construct foreign financial variables-EDFs, real money market rate, share price index and real effective exchange rate - and trade weights for industrial production.

\section{B. Sample, Variables, and Weights}

The GVAR model covers 30 economies, including 21 advanced-Austria, Australia, Belgium, Canada, Denmark, Finland, France, Germany, Hong Kong S.A.R., Ireland, Italy, Japan, the Netherlands, New Zealand, Norway, Singapore, Spain, Sweden, Switzerland, the United Kingdom, and the United States - and 9 emerging economies - Brazil, China, India, Indonesia, Malaysia, Mexico, the Philippines, South Africa, and Turkey.

Macroeconomic and financial data are of monthly frequency and cover the period from January 1996 to December 2008. All data, except the EDFs, are obtained from the IMF's International Financial Statistics, CEIS and GDS. The sample period is constrained by the availability of data for emerging economies. See Appendix I for detailed information about data sources and transformations as well as descriptive statistics. In particular, note that the 
standard deviations of bank and corporate EDFs are similar, implying that the effects of shocks to these variables are comparable.

Measures of financial distress, EDFs, are from Moody's KMV (MKMV). MKMV is a commercial product that uses a modified version of the Merton model (1974) to calculate the expected default frequency (EDFs) for 35,000 financial institutions and nonfinancial corporates in 55 economies (see Gray and Malone, 2008; and Gray, Merton, and Bodie, 2008 , for details). A firm is in default when the market value of its assets falls short of its debt obligations. The likelihood of default depends on the current value and risk (volatility) of its assets relative to the promised payments on the debt (defined as the default barrier). The implied asset value and volatility are estimated by applying a modified version of the Merton model to equity market data and balance sheet information. For more details on the Merton model and contingent claims analysis, see Appendix II.

The EDFs combine equity price data with data on firms' balance sheet data and often exhibit nonlinear characteristics, reflecting the impact of a broad range of factors, such as the structure of a firm's balance sheet and investors' risk appetite, on the probability of the firm's default. For example, correlations between EDFs for U.S. banks and corporates and U.S. stock prices, in level terms, are 0.3 and 0.6 respectively, while correlations between changes in the respective variables (which are used in the GVAR model) are close to zero. To create country-specific measures of EDFs, we use the time-varying asset-weighted averages of one year-ahead EDFs for all banks and (nonfinancial) corporates. The average number of banks and corporates in emerging and advanced economies does not vary significantly, suggesting that the coverage of firms should not bias the results. See Appendix I for the number of firms in each country.

In GVAR, the bilateral dependence of domestic variable on a foreign variable is proportional to the country-specific weight used to form foreign variables. We use broad financial and trade weights to form foreign values of financial and macroeconomic variables, respectively. This is in contrast to the previous GVAR literature which uses trade weights or narrow financial weights (covering only bank lending relationship) to form foreign values of financial variables (Dees and others, 2007; Galesi and Sgherri, 2009, respectively). Using the above mentioned financial weights advances the GVAR literature in the direction of improving the model's ability to capture the financial channels of shock transmission.

Financial weights are constructed using currency exposure measures of Lane and Shambaugh (2010), which summarize bilateral financial asset positions in five instruments: portfolio equity, direct investment, portfolio debt, other general bank-related debt, and reserves. We take the average weight from 1999 to 2004 (the latest data for which Lane and Shambaugh's data are available) as a fixed weight for the four financial variables in the model (Table 1). To construct measures of foreign industrial production, we use trade weights. These weights are constructed based on the IMF's Direction of Trade Statistics as the share of bilateral goods trade in total trade, averaged over the period from 1996 to 2008 (Table 2).

Data limitations, especially for data on financial asset positions, prevent us from using timevarying weights. However, this may not be a major issue as the bilateral patterns of assets 
and liabilities for most countries in the sample have remained broadly stable during 1999 2004. Also, as shown in Pesaran et al (2004), the GVAR results are robust to using timevarying (trade) weights. We explore alternative ways to form foreign financial and real sector variables as part of robustness checks.

\section{Impulse Responses}

Given the short sample period, the study focuses on short-run dynamics. The model is estimated in first differences as the macroeconomic and financial data are found to be integrated of order 1. Identifying the complete set of shocks in equation (8) and computing the impulse response functions in a GVAR model is not straightforward. It requires imposing an enormous amount of identification restrictions due to the large number of economies covered in the study. Therefore, we identify shocks following the approach in Dees and others (2007) and Binder, Chen, and Zhang (2009).

To identify shocks to EDFs of U.S. banks and corporates, for example, we first identify structural shocks in the VARX* for the United States, using Cholesky decomposition and assuming a Wold ordering of $y_{i t} \quad r_{i t} \quad p_{i t}^{s} \quad q_{i t} \quad e d f n_{i t} \quad e d f b_{i t}$. Ordering industrial production first means that it does not respond contemporaneously to the financial shocks. The real short-term interest rate is assumed to react contemporaneously to industrial production shocks, consistent with a Taylor rule. Share prices are allowed to respond to industrial production and the real interest rate, as they reflect expected future macroeconomic fundamentals. The exchange rate is assumed to react to all variables except the EDFs.

The EDFs are assumed to react to all four variables on the grounds that the industrial production shock affects future profits of banks and corporates and hence their default probabilities, while the real interest rate, share price index, and the exchange rate also enter into the calculation of the EDFs through the maturity and composition structure of institutions' balance sheets. We assume that bank EDFs respond to shocks to corporate EDFs, and not the other way around, because loans to corporates constitute a significant portion of banks' assets. An increased likelihood of corporate default is likely to affect bank default probabilities as the quality of banks loan portfolio deteriorate. Of course, one may argue that an unexpected change of bank default probability due to, say, the shortage of liquidity can raise corporate default probabilities because of the tightening of lending conditions. Placing banks' EDFs before corporates' EDFs in the GVAR does not alter the main findings.

The U.S. domestic variables are assumed not to react to shocks to other economies' variables, which amounts to ordering the U.S. economy first. As part of robustness checks, we confirm that an alternative ordering of the remaining economies does not change the impulse response function for the U.S. shocks.

After identifying the EDF shocks, we compute impulse responses of the other variables in the global solution in equation (8) based on correlations between the reduced form shock of each variable and the identified structural shock of the EDF. Such an identification scheme means that zero correlation between the structural EDF shocks and other domestic variables in each 
economy need not be imposed and the transmission of the shock is determined without any additional restrictions. The impulse response of variables in other economies are computed similarly to the generalized impulse response, which leaves the contemporaneous correlations of the U.S. EDF shocks and structural shocks in other countries unrestricted.

We consider temporary shocks to U.S. bank and corporate distress. Each shock is assumed to last for one month and amount to a one percentage point increase in the default probability of banks and corporates. Since we have controlled for changes in the macroeconomic fundamentals and stock prices that may affect the EDFs, the innovation to the residual should be interpreted as an unexpected shock that worsens the balance sheets of firms and augments the EDF. The correlations of the U.S. EDF shocks and the contemporaneous macroeconomic and financial variables are close to zero.

These shocks usefully illustrate the channels through which bank and corporate distress can be transmitted across the world. However, they are not necessarily suggestive of patterns of contagion during financial crises because bank and corporate distress is likely to be more persistent and greater in magnitude than what is assumed in the paper. Distress during crises may also be associated with nonlinear effects, for example, owing to changes in market liquidity. Such nonlinear effects are not captured in the GVAR.

\section{Transmission OF BanK AND CORPORATE Distress}

The results show that financial distress has significant effects on domestic economies activity, with bank and corporate default, equity prices and real activity being affected in tandem. The strength of international spillovers from bank and corporate distress depends on the importance of the economy where the shock originates from. Although the macroeconomic effects of bank and corporate distress are in many ways similar, there are also notable differences. In particular, corporate distress in advanced economies has a larger impact on economic growth in emerging economies than bank distress in advanced economies. On the other hand, advanced economies are more vulnerable to bank distress than to corporate distress. These results are robust to various changes in specification. In addition, we find that controlling for the strength of bank and corporate balance sheets in GVAR amplifies the effects of real and financial sector shocks.

\section{A. Domestic Impact of Bank and Corporate Distress}

The impulse response functions associated with a 1 percentage point increase in the probability of default of U.S. banks show that the expected probability of corporate defaults immediately starts to rise, with the impact peaking at about 0.3 percentage points one month after the initial shock (Figure 1). The comovement between bank and corporate default risk (albeit with a lag) reflects the transmission of the shock through the banks' balance sheets, whereby weaker banks tighten lending conditions, hurting borrowers' balance sheets and pushing up their default risk. Higher bank and corporate default risks lead to declines in stock prices (with a maximum impact of 10 percentage points one month after the initial shock) as investors anticipate weaker earnings. The effects on corporate default risk and stock prices are statistically significant at the 90 percent significance level, underscoring the importance of financial and balance sheet channels in the transmission of financial distress. 
Other macroeconomic variables move in the expected direction. Industrial production falls, with the maximum impact of 0.3 percentage points two months after the initial shock. The real short-term interest rate rises during the first month after the shock, consistent with the tightening of lending conditions, but over the subsequent months, it declines, likely reflecting an easing of monetary policy. The effects on industrial production and the real interest rate are statistically significant, albeit only two-three months after the initial shock. Prior to this, responses are typically statistically insignificant. The real effective exchange rate depreciates in the first two months after the initial bank distress shock, consistent with slowing economic activity, rising corporate default risk and declining stock prices. These effects are statistically insignificant during the full one year after the shock.

The effects of a 1 percentage point increase in the default probability of U.S. corporates on financial variables are broadly similar to those of an increase in banks distress risk, confirming close linkages between the health of the corporate and banking sector (Figure 2). Bank default risk rises (with the maximum impact of about 0.3 percentage points) within a month after the increase in corporate default risk, as the deterioration in corporate balance sheets worsens the quality of banks' loan portfolio. Stock prices fall (with the maximum impact of about 13 percentage points). These effects are statistically significant, as before, pointing to the strength of linkages between distress in bank and corporate balance sheets and financial markets.

Other macroeconomic variables behave as expected. Industrial production declines, although this effect is statistically insignificant. The real effective exchange rate appreciates by about 2 percentage points, and this effect is statistically significant. One possible explanation is that a shock to corporate default risk may be akin to a negative supply-side shock and be associated with a pickup in inflation. The real interest rate declines as in the case of a bank distress risk shock, although the decline is statistically insignificant.

Shocks to the default probabilities of banks and corporates in other economies have similar effects. The degree of comovement in the default risk of banks and corporates varies, possibly reflecting different degree of financial development, the importance of the corporate sector exposures for banks, and availability of alternative financing sources for (nonfinancial) corporates.

\section{B. International Propagation of Bank and Corporate Distress}

Bank and corporate distress in systemically important economies have significant international implications. For example, a 1 percentage point increase in the default probability of U.S. banks immediately raises the probability of German banks' default by about 0.2 percentage points, possibly reflecting an expectation of a tightening of funding conditions and losses on holdings of U.S. assets as well as weaker demand for German export products (Figure 3). The default probability of German corporates rises by approximately the same magnitude as the default probability of German banks immediately after the shock. Industrial production in Germany declines by a larger magnitude than that in the United States, possibly because the real effective exchange rate for the euro appreciates in contrast to that for the dollar. Bank distress may also have a larger impact on real activity 
in Germany than in the United States, because bank credit is a more important source of funding for German corporates than for their U.S. counterparts.

The impact of an increase in the default probability of U.S. banks on emerging economies is also significant. For example, as shown in Figure 4, a 1 percentage point increase in the default probability for the U.S. banks raises the default probability of Brazilian corporates (with the maximum impact close to 1 percentage point). This is a larger effect than that on German corporates, albeit with a one month lag in contrast to the immediate impact on the default risk of German corporates. The larger impact on the corporate default risk in Brazil is consistent with a larger decline in industrial production (by close to 5 percentage points on impact), more than double the impact on Germany's industrial production. It may reflect the fact that Brazil experiences a dual shock of lower demand from the United States and other advanced economy partners, namely Europe and Japan. Although the immediate impact on industrial production is significant, a large depreciation of the exchange rate, helps mitigate the impact on real economic activity and the initial decline in industrial production quickly unwinds. Share prices fall by as much as 15 percent.

Surprisingly at the first glance, the default risk of Brazilian (and Mexican) banks declines in response to the increase in the default risk of U.S. banks. One possible explanation is that the quality of banks' loan books improves as high-quality domestic borrowers substitute away from foreign bank borrowing toward domestic banks. Another explanation, put forward by Kamil and Rai (forthcoming), is that foreign banks' involvement in Latin America tends to differ from that in other regions: it is mostly conducted through local subsidiaries, with loans denominated in domestic currency and funded through domestic deposits. These differences may help explain why global deleveraging has not affected Latin America as much as other emerging markets during the recent financial crisis.

In contrast to Brazil, an increase in the default probability of U.S. banks has an adverse impact on the default probability for both Chinese banks and corporates. These probabilities rise by about 0.5 percentage points in the first month after the shock (Figure 5 ). The impact on stock prices and real effective exchange rate is smaller than those in Brazil. The effects on the real interest rate and industrial production are statistically insignificant over the entire horizon of one year.

The direction of the effects of shocks to the default probability of U.S. corporates on Germany, Brazil and China is broadly similar to those of shocks to the default risk of U.S. banks (Figures 6-8). The effects on the default probability of Chinese banks and corporates are larger in magnitude, suggesting that production chain linkages between China and the United States tend to be larger than those through the financial channels, which is consistent with China's capital account being closed.

The effects of the U.S. bank and corporate distress on other advanced and emerging economies are summarized in Figures 9-10. Distress in U.S. banks and corporates has a significant adverse impact throughout the world, with the magnitude of the impact depending on the strength of financial and trade linkages of the economy in question to the United States, where the shock originates, as well as various structural features of the economy and 
its policy framework. A 1 percentage point increase in the default probability of U.S. banks is estimated to result in a $0.3-0.5$ percentage point increase in the default probability of banks in China, India, Japan and other advanced Europe. The impact on the euro area, Pacific (including Australia and New Zealand) is smaller, around $0.1-0.2$ percentage points, while the default probability of the Latin American banks tends to improve, as discussed above.

Distress in the U.S. banking sector tends to be transmitted to the nonfinancial corporate sector, particularly in Latin America and emerging Asia. The apparently close relation between U.S. bank distress and corporate distress in emerging economies may reflect the price sensitivity and reliance of emerging economies' corporates on overseas borrowing from advanced economies' banks, particularly from the United States. The magnitude of the shock transmission to Japan, Pacific (Australia and New Zealand), the euro area, and other advanced economies in Europe is weaker, possibly because of their greater reliance on the domestic sources of funding in contrast to the role of overseas financing in emerging economies.

Industrial production falls in all advanced and emerging economies in response to distress in the U.S. corporate sector. Japan and Latin America are most affected, reflecting their close production and trade linkages with the United States and the composition of their trading partner groups more generally. Consistent with the decline in real activity and a rise in default risk of banks and corporates, stock markets fall across the world. India, Latin America, Newly Industrialized Economies in Asia, and the euro area experience the largest declines in real stock prices (around 15 percentage points). Like in response to U.S. bank distress, a decline in stock prices in China is much smaller than in India, reflecting, among other things, its less open capital account and less developed capital markets. Effects on the real effective exchange rate are mixed, ranging from a 6 percentage point appreciation in Japan to close to 5 percentage point depreciation in Latin America, Australia and New Zealand. The effects of a 1 percentage point increase in the default probability of U.S. corporates are broadly similar to those of the shock to the default probability of U.S. banks.

The aggregation of the impact on emerging and advanced economies shows the similarities and differences in the effects of the U.S. bank and corporate distress on these economies' financial distress (Figure 11). U.S. bank distress has a larger impact on the default probability of banks in advanced economies than those in emerging economies, consistent with the former's greater financial openness and integration. The impact of U.S. bank distress on advanced economies' (and global) industrial production is also greater than in response to the U.S. corporate distress, possibly reflecting larger financial accelerator effects associated with the shocks originating in the banking sector as well as greater financial openness of advanced economies than emerging economies. The impact of U.S. bank distress on corporate distress is larger for emerging economies than advanced economies possibly owing to the greater reliance of emerging economies' corporates (especially larger firms) on overseas financing or their greater price sensitivity to financial conditions proxied by U.S. bank distress.

The effects of bank and corporate distress on other macroeconomic and financial variables in advanced and emerging economies are also quite different (Figures 11-12). First, the impact of U.S. corporate distress on industrial production in emerging economies is considerably 
larger than that in advanced economies (about $3 \frac{1}{2}$ percentage points compared to less than 1 percentage point), consistent with greater trade openness of these economies than that of advanced economies. Other possible reasons are a larger impact on emerging economies' banks and appreciating exchange rates under the U.S. corporate distress shock. Second, the impact of the U.S. corporate distress shock on industrial production in emerging economies also exceeds that of the U.S. bank distress shock, possibly owing to greater importance of trade channels than financial channels in the transmission of shocks to emerging economies. Third, emerging economies' central banks tend to respond more aggressively to shocks emanating from the U.S. corporate sector than from the U.S. banking sector, as reflected in a decline in real interest rates under the former shock and an increase under the latter. This could reflect stronger concerns about the impact of U.S. corporate distress on real activity than direct impact from U.S. bank distress on its own, given strong production linkages. All in all, the findings are broadly consistent with recent crisis experiences, including the larger impact on banking sectors and economic growth in advanced economies than emerging economies.

Shocks to the default probability of banks and corporates in other economies have similar, albeit weaker effects than those of the U.S. shocks, consistent with other economies' smaller role in the global economy and finance than that of the United States.

\section{Robustness Analysis}

The results are qualitatively robust to a variety of changes in model specifications, including applying the average of trade and financial weights to foreign variables instead of using financial weights for financial variables and trade weights for the real activity variables. The averages take into account the possibility that shocks to all variables are transmitted through both trade and financial channels equally. The results remain very similar to those based on the original specification, including the effects on domestic and spillovers to other economies. However, the magnitude of the effects on the real interest rate vary for some economies, suggesting that the nature of transmission channels has significant bearing on the macroeconomic effects of shocks, particularly on inflation, and hence the monetary policy response.

The results are also robust to using an alternative Wold ordering, particularly, switching the order of bank and corporate default probabilities to allow for the corporate EDF to respond to the bank EDF shock contemporaneously. The rationale for this modification is to allow for the possibility that bank and corporate balance sheets to worsen following a tightening of monetary policy and lending conditions. The results are qualitatively consistent with those based on the original specification, although the ordering of economies by the maximum impact of shocks changes slightly.

Similarly, replacing the real effective exchange rates with bilateral real exchange rates also does not affect the results significantly. The number of observations is insufficient to test the robustness of the results to changes in the sample time period. However, we confirmed that the exclusion of a limited number of economies from the sample does not affect the results significantly. 
In addition to the above robustness tests, we examined how the inclusion of bank and corporate default probabilities in the GVAR model affects the direction and magnitude of the macroeconomic effects of shocks and their transmission. We find that the inclusion of these credit risk measures tends to amplify the transmission of shocks (Figure 13). This finding suggests that incorporating additional measures of bank and corporate credit risk in a macroeconomic VAR model helps better account for the various financial accelerator mechanisms and bank capital channels.

\section{CONCLUSION}

This paper examined how distress in banks and corporates affects domestic economies and gets transmitted to other economies. The analysis is based on a parsimonious GVAR model covering 30 advanced and emerging economies and including not only macroeconomic and financial variables such as stock prices and interest rates but also forward-looking measures of default probabilities for banks and corporates. The model controls for common global shocks, such as oil prices, and uses broad measures of financial exposures to account for various financial channels through which shocks are transmitted across the world.

The analysis confirms strong macro-financial linkages within domestic economies and globally. Bank and corporate distress, especially when originating in systemically important economies, can have adverse implications for global real activity, with stark differences between advanced and emerging economies. Growth in emerging economies is more sensitive to corporate than bank distress, while the opposite is true for advanced economies. This finding may reflect a lower level of financial development of emerging economies compared to advanced economies. Lower financial openness and greater trade openness of emerging economies may also play a role as it implies greater importance of trade and production linkages as channels through which emerging economies are integrated in the global economy. These conclusions are qualitatively robust to a variety of changes in model specification and broadly consistent with experiences during the recent financial crisis. 
Figure 1. Domestic Impact of One Percentage Point Increase in the U.S. Bank Default Probability
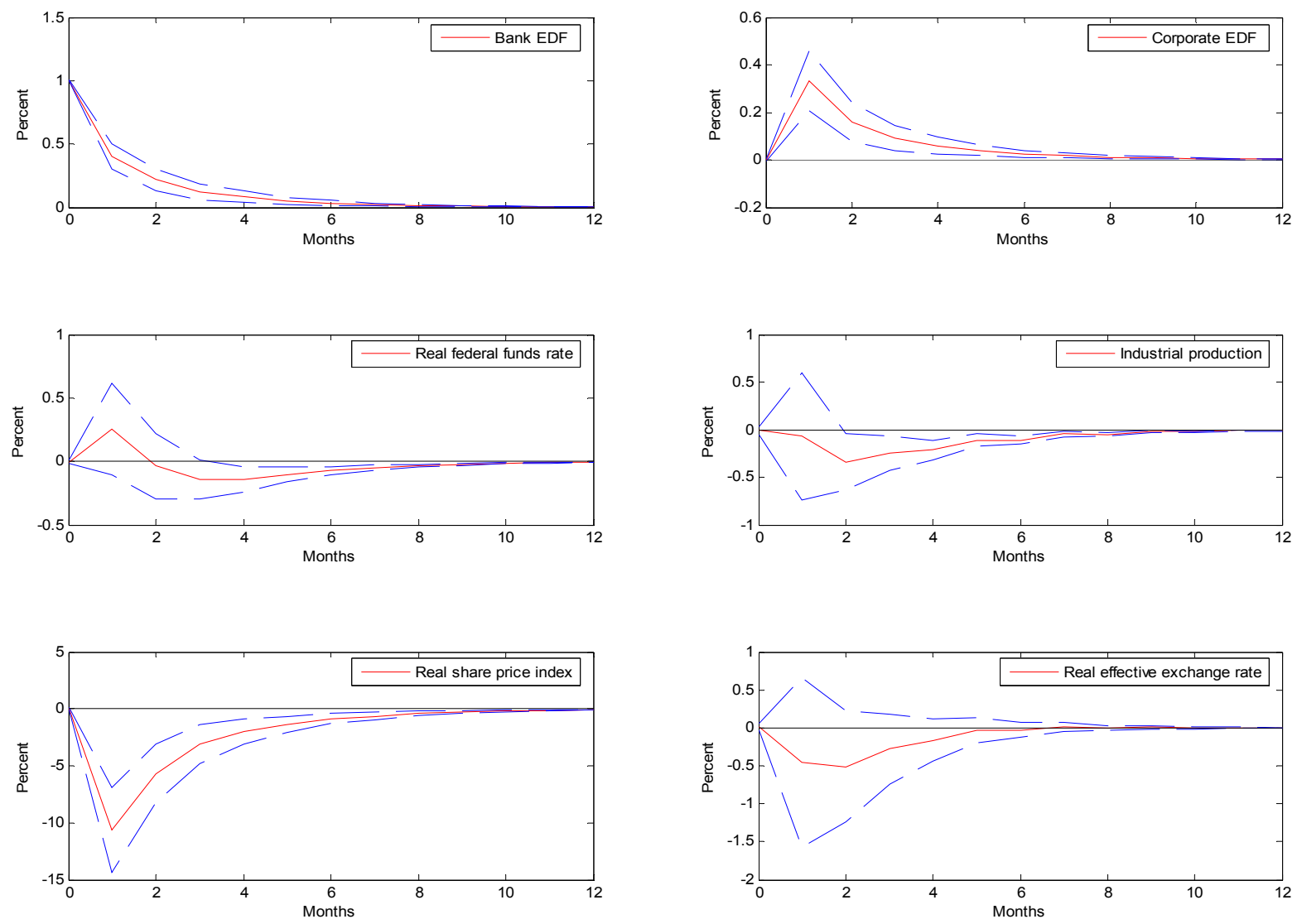

Source: Authors' estimates.

Note: 90 percent confidence bands. 
Figure 2. Domestic Impact of One Percentage Point Increase in the U.S. Corporate Default Probability (In percentage points)
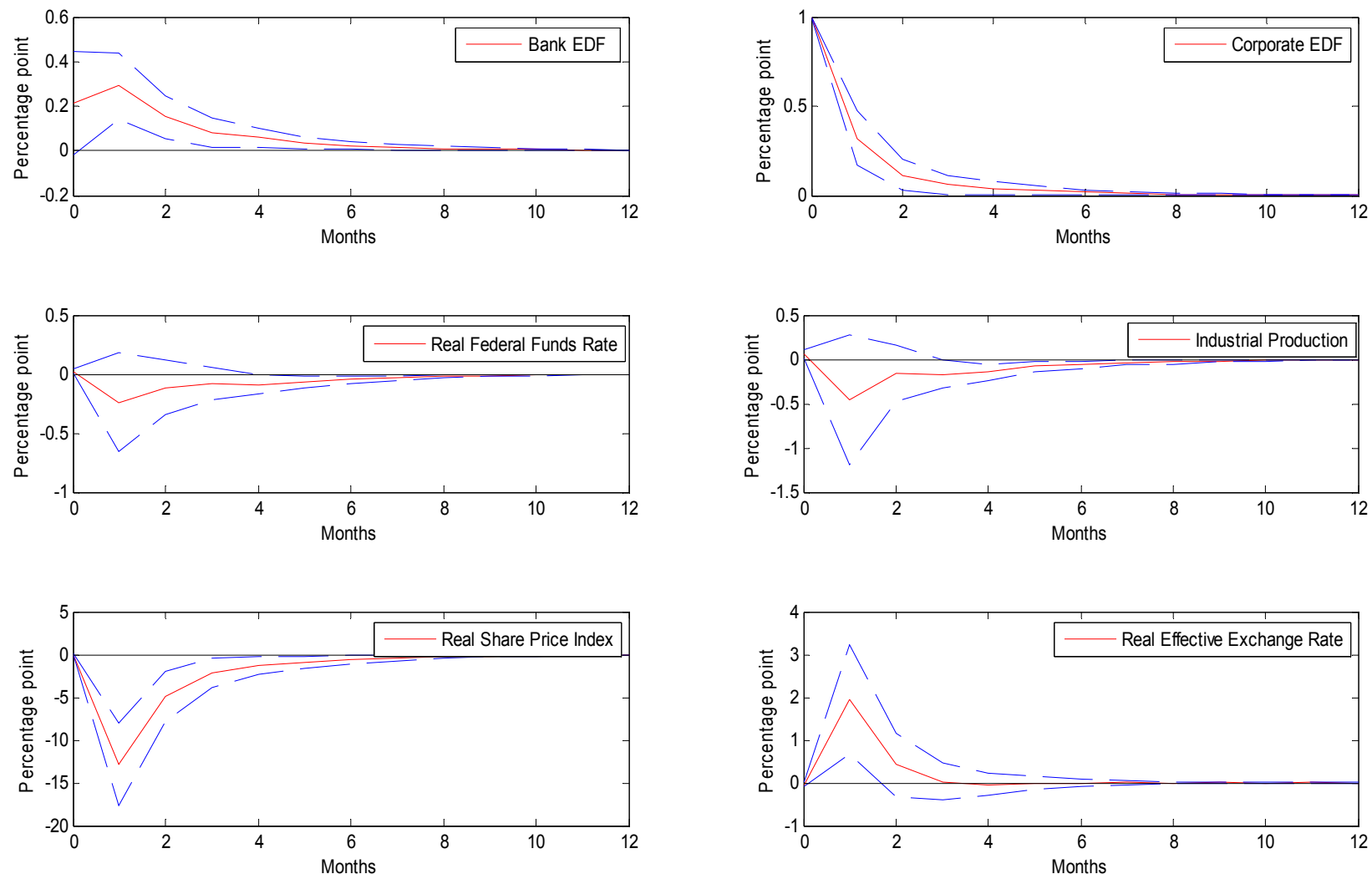

Source: Authors' estimates.

Note: 90 percent confidence bands. 
Figure 3. Impact of One Percentage Point Increase in the U.S. Bank Default Probability on Germany (In percentage points)
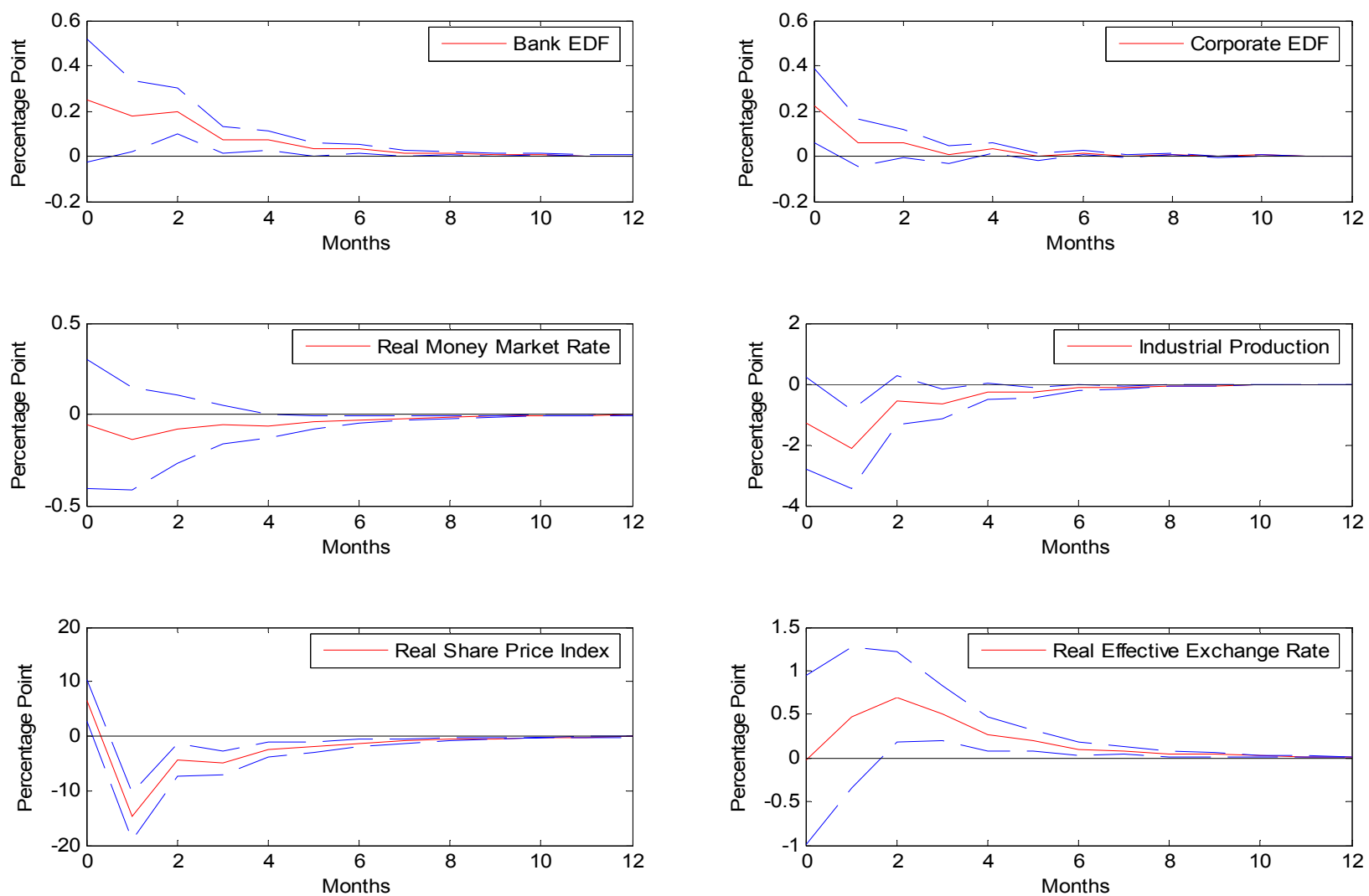

Source: Authors' estimates.

Note: 90 percent confidence bands. 
Figure 4. Impact of One Percentage Point Increase in the U.S. Bank Default Probability on Brazil (In percentage points)
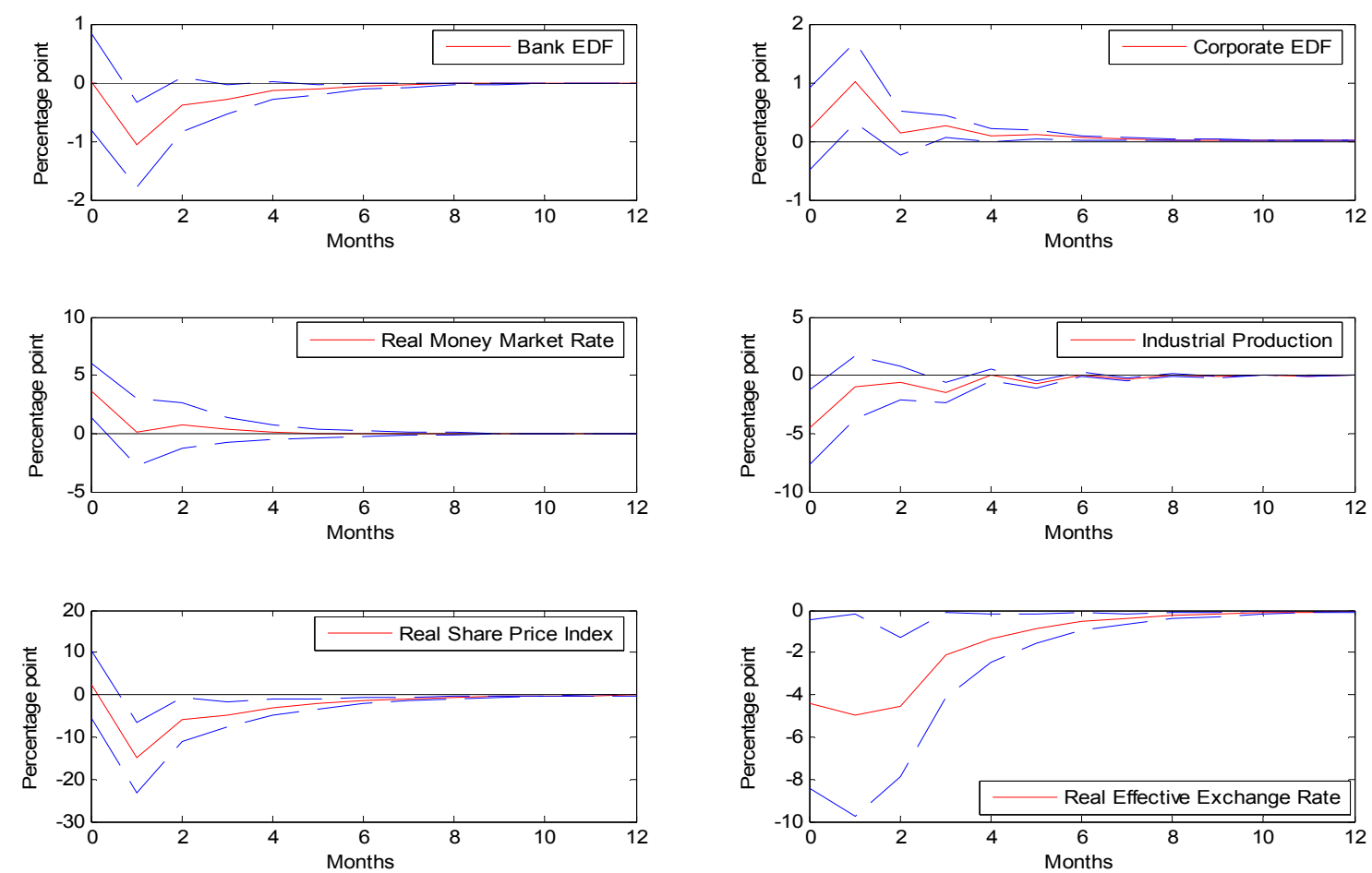

Source: Authors' estimates.

Note: 90 percent confidence bands. 
Figure 5. Impact of One Percentage Point Increase in the U.S. Bank Default Probability on China (In percentage points)
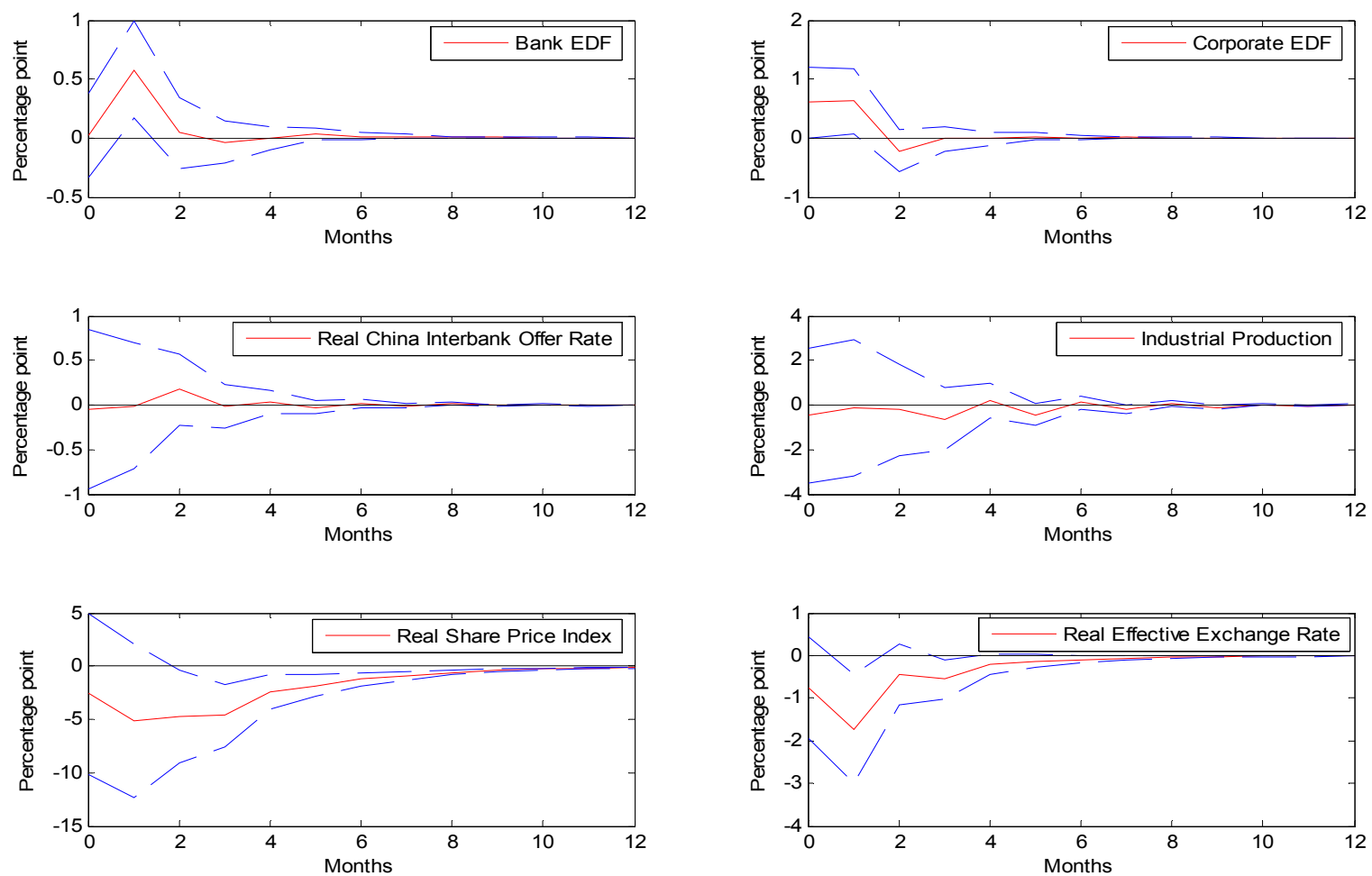

Source: Authors' estimates.

Note: 90 percent confidence bands. 
Figure 6. Impact of One Percentage Point Increase in the U.S. Corporate Default Probability on Germany (In percentage points)
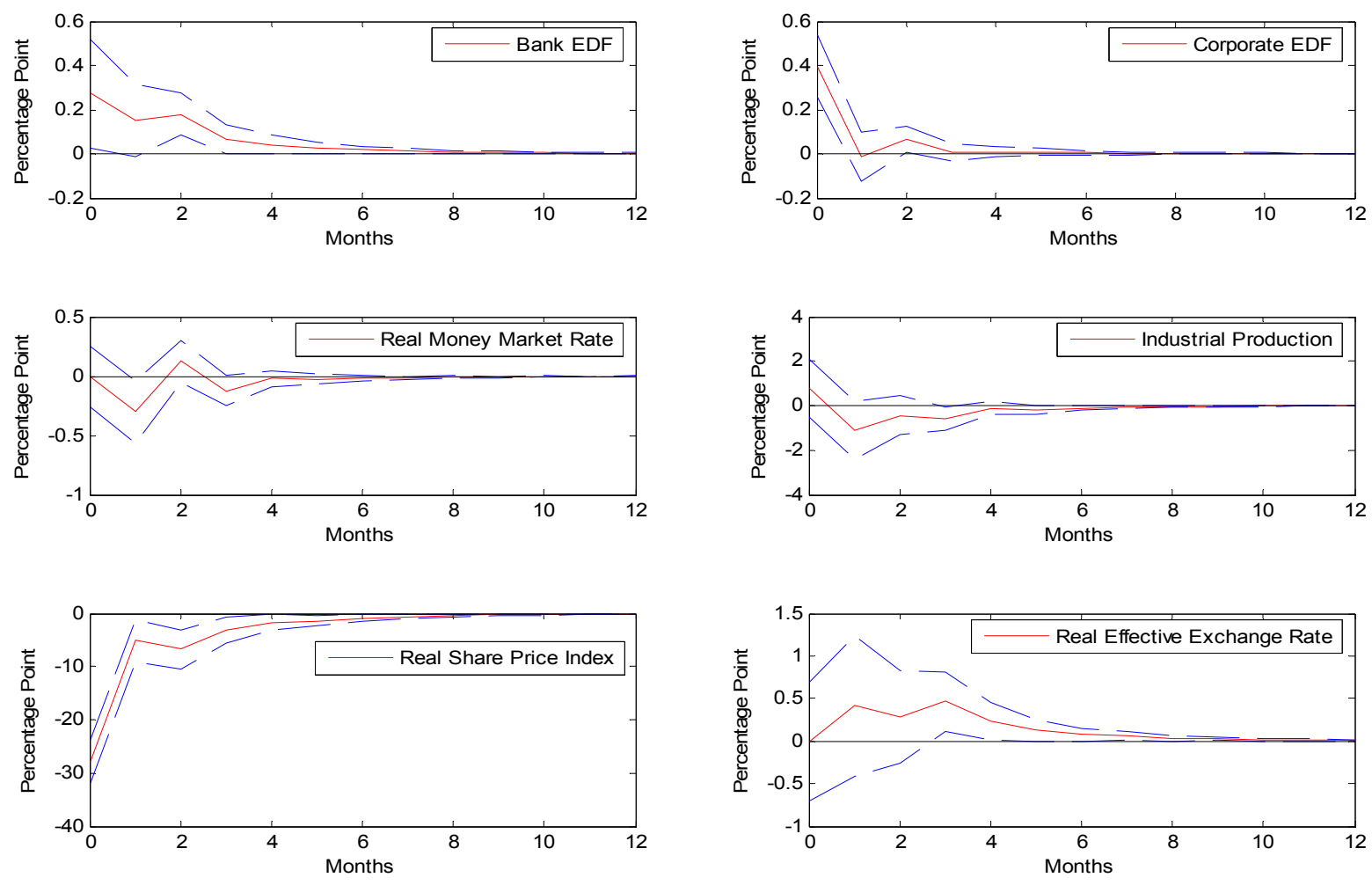

Source: Authors' estimates.

Note: 90 percent confidence bands. 
Figure 7. Impact of One Percentage Point Increase in the U.S. Corporate Default Probability on Brazil (In percentage points)
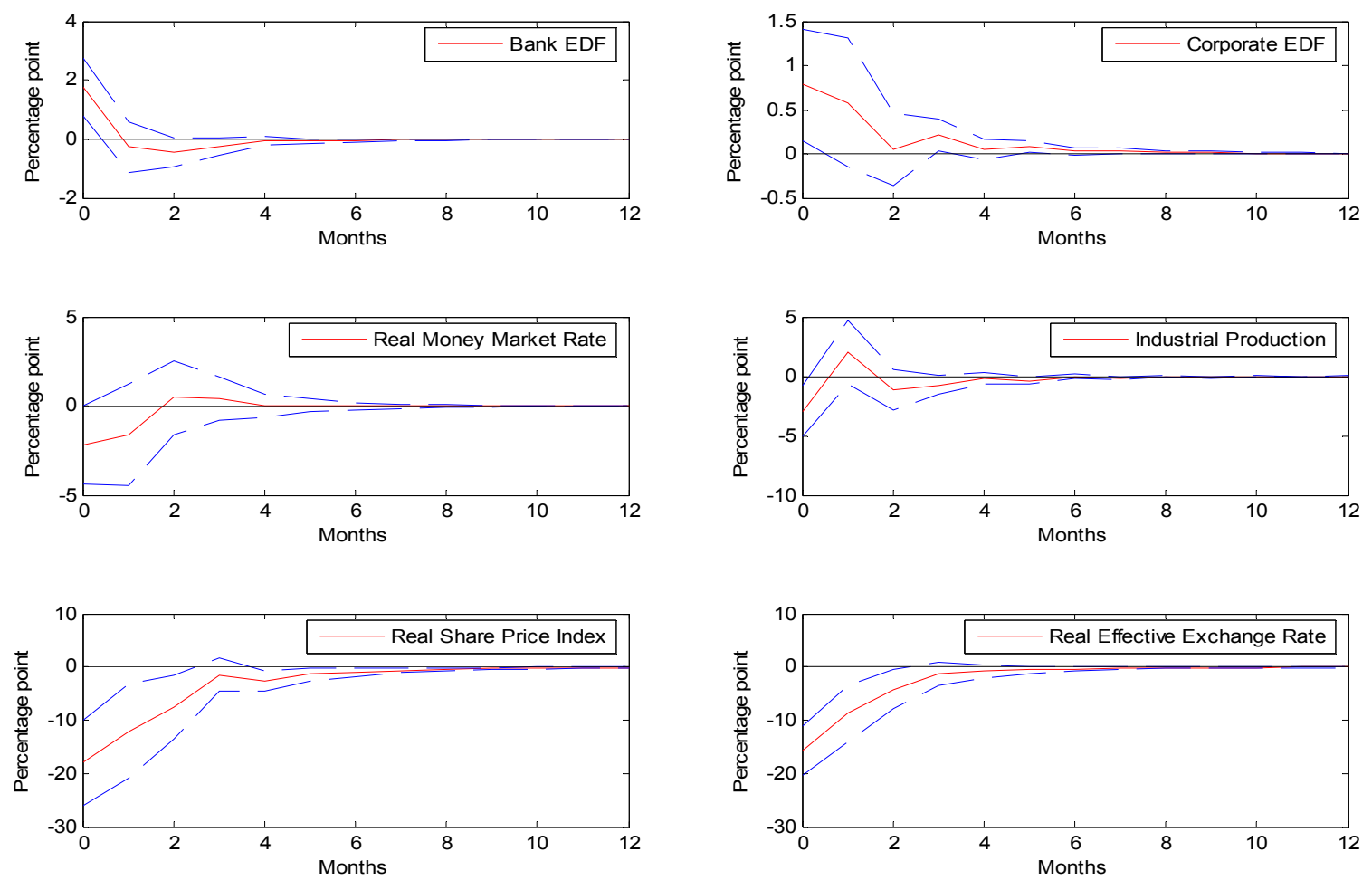

Source: Authors' estimates.

Note: 90 percent confidence bands. 
Figure 8. Impact of One Percentage Point Increase in the U.S. Corporate Default Probability on China (In percentage points)
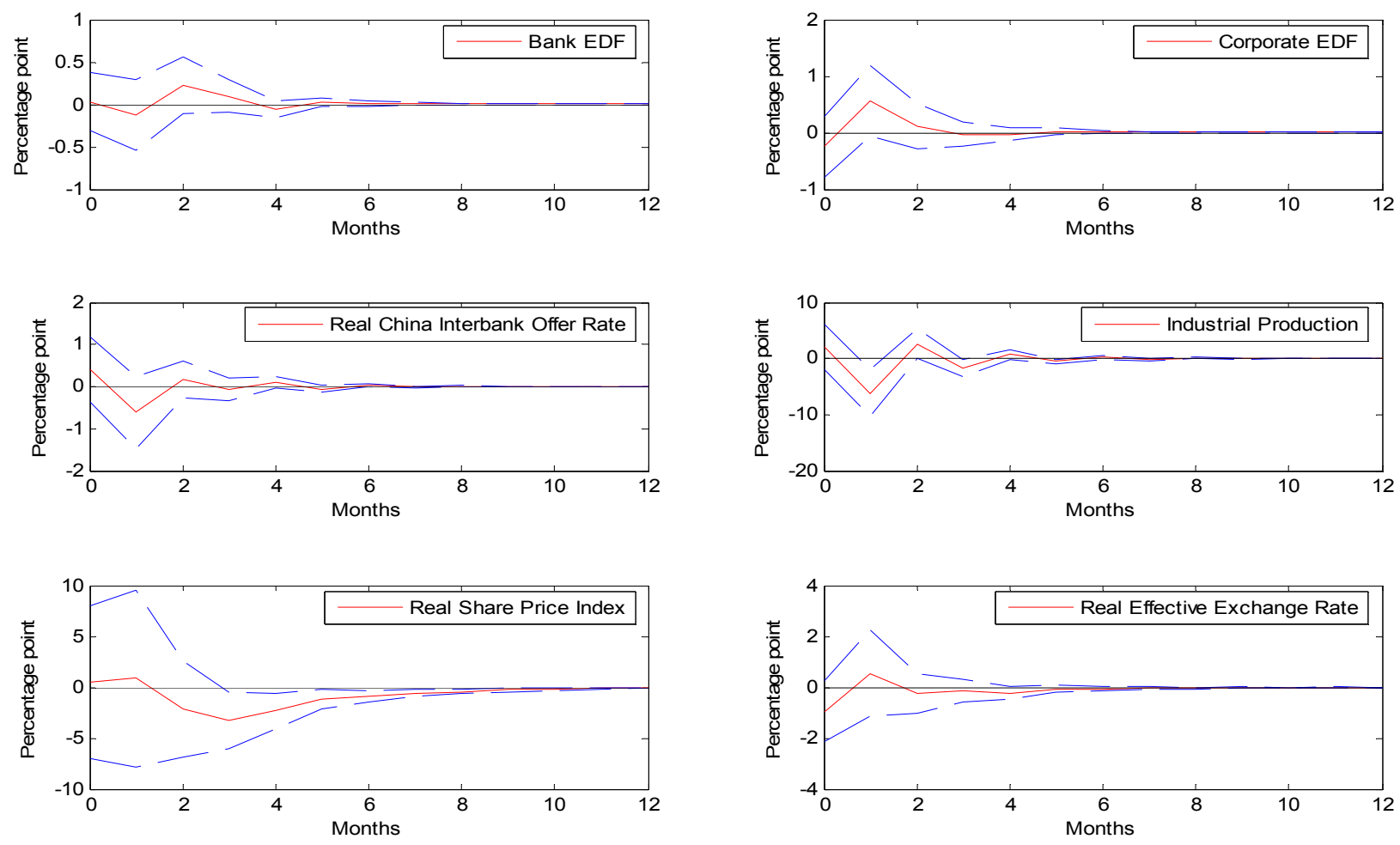

Source: Authors' estimates.

Note: 90 percent confidence bands. 
Figure 9. Maximum Impact of One Percentage Point Increase in the U.S. Bank Default Probability

(In percentage points)
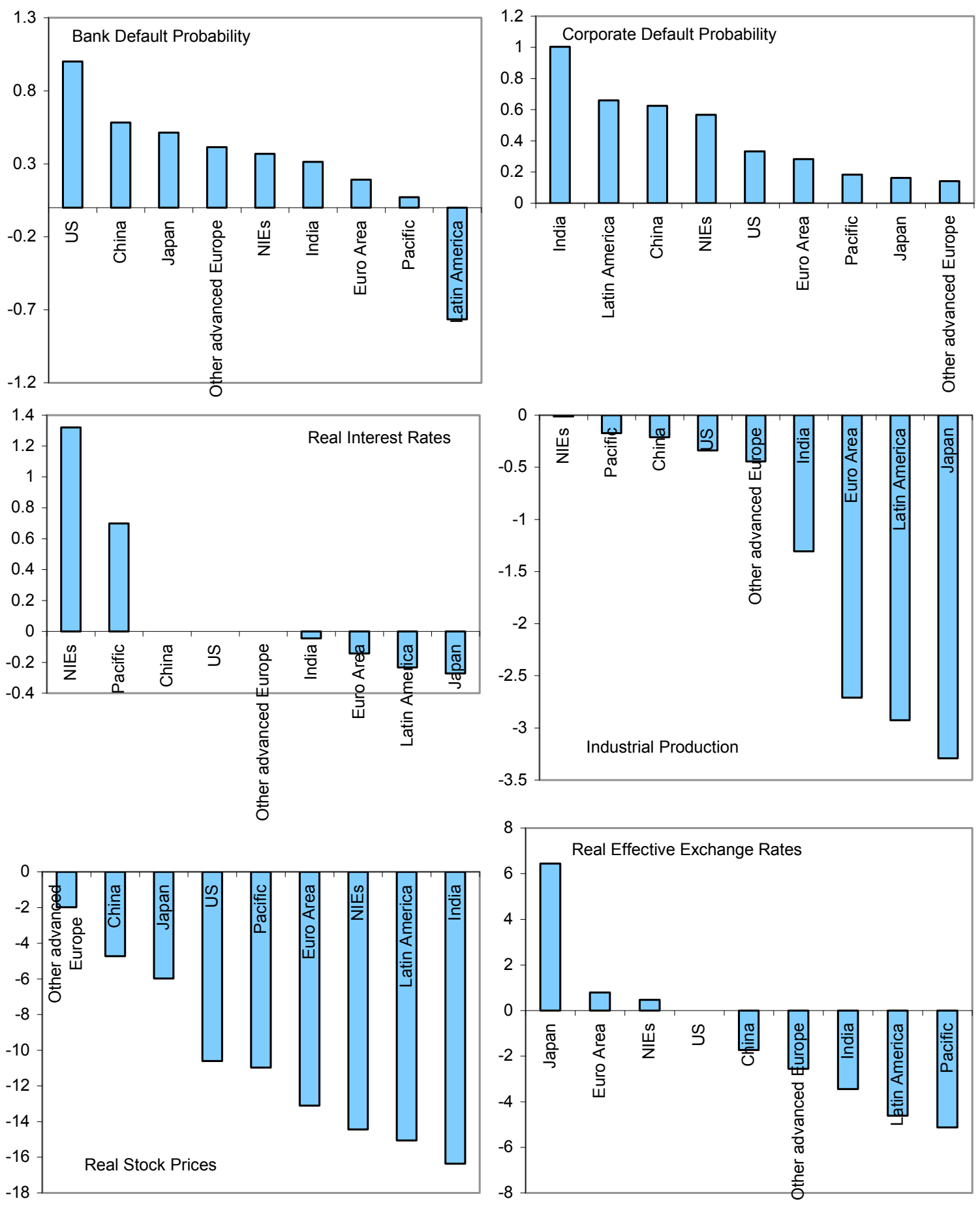

Source: Authors' estimates. 
Figure 10. Maximum Impact of One Percentage Point Increase in the U.S. Corporate Default Probability

(In percentage points)
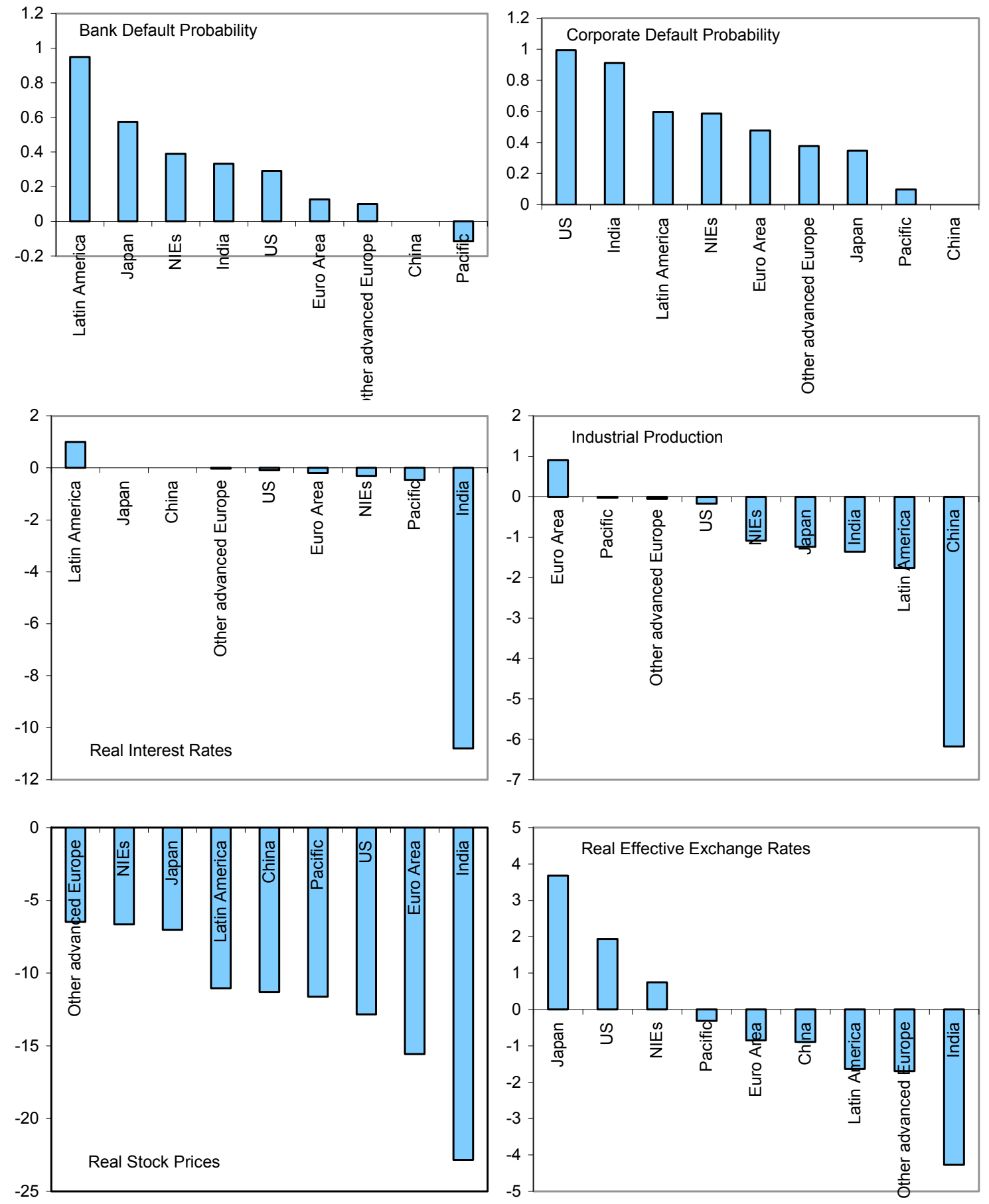

Source: Authors' estimates.

Note: Weighted by PPP-adjusted GDP. 
Figure 11. Average Impact on Advanced and Emerging Economies (In percentage points)

One Percentage Point Increase In U.S. Bank Distress

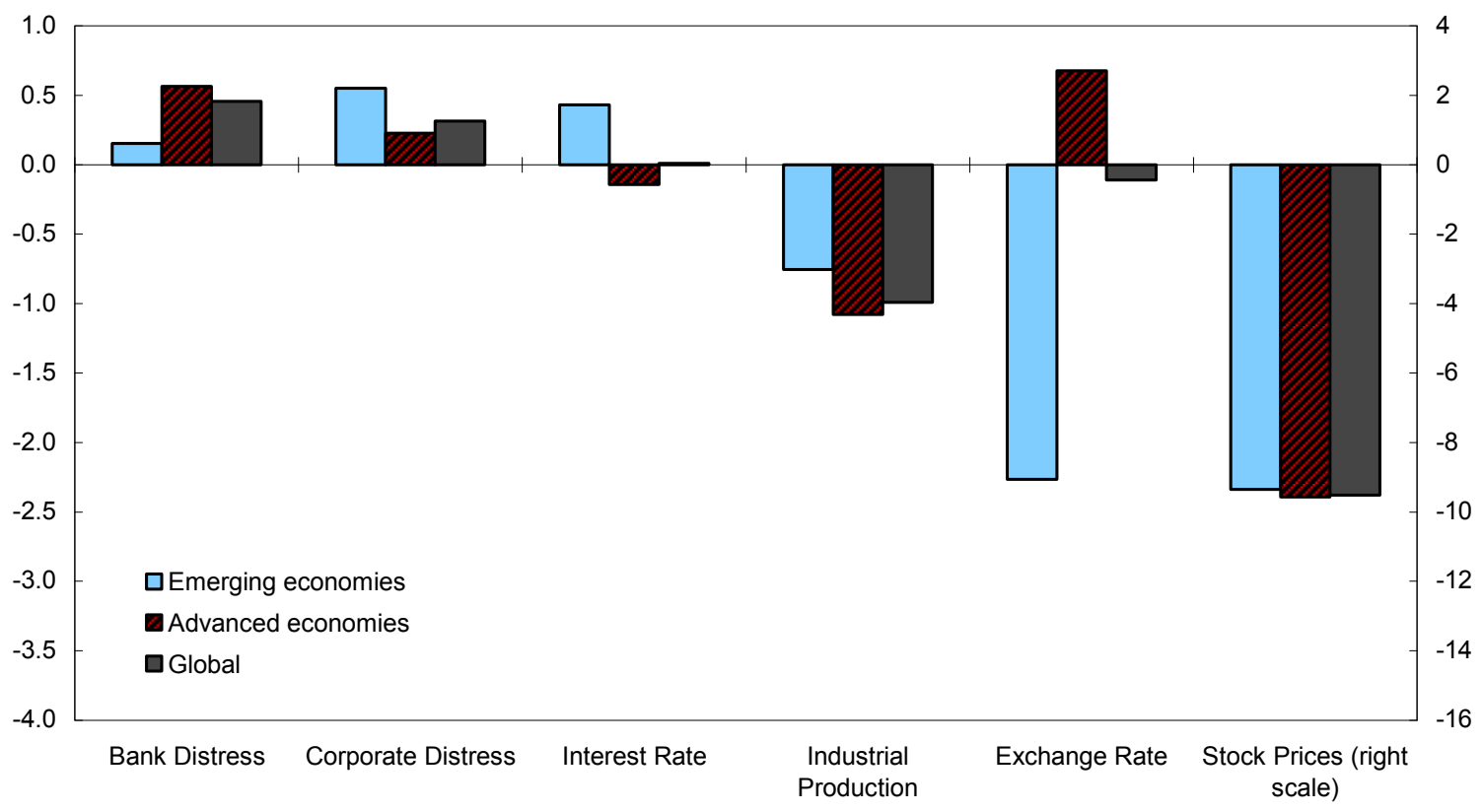

One Percentage Point Increase in U.S. Corporate Distress

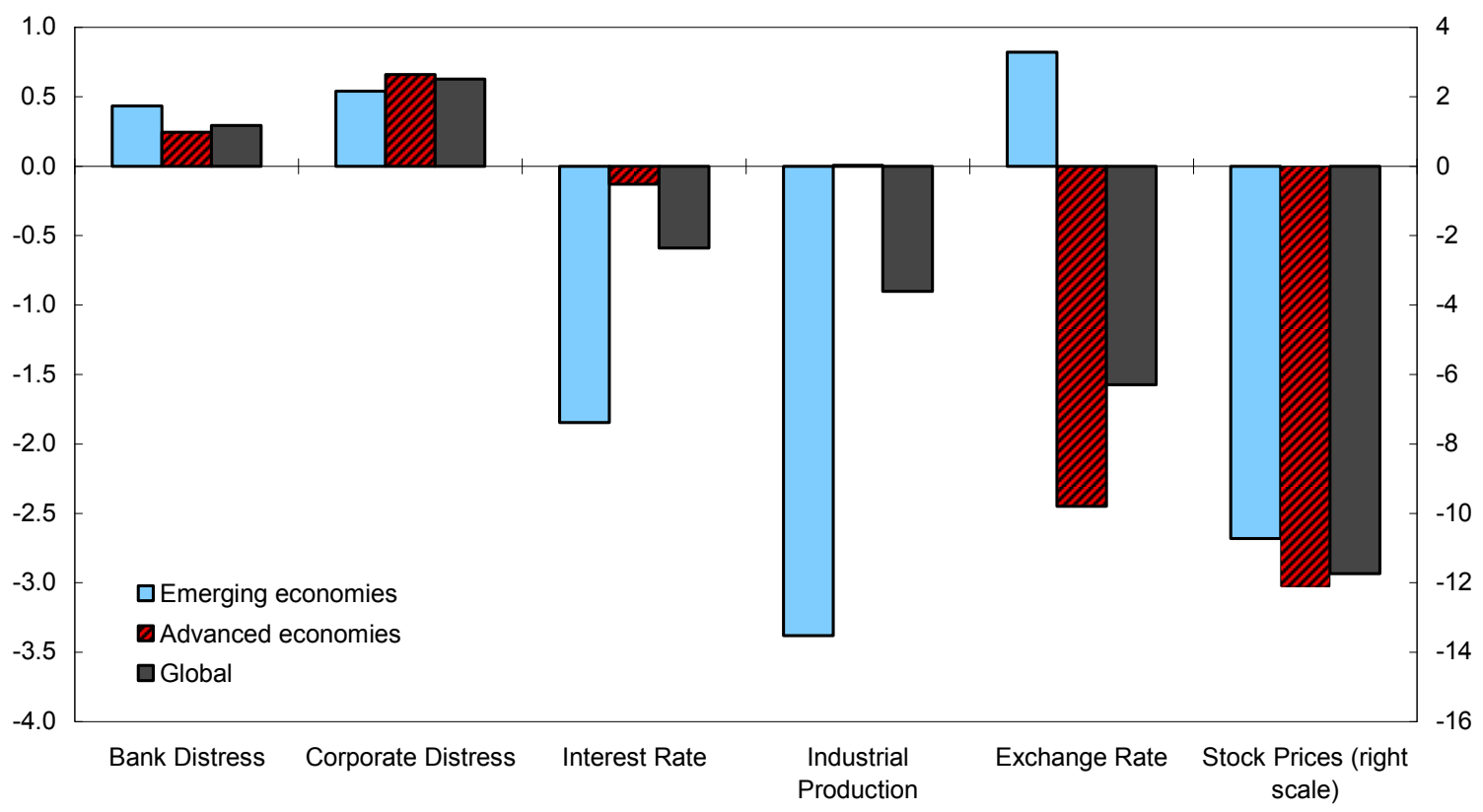

Source: Authors' estimates. 
Figure 12. Global Transmission of U.S. Bank and Corporate Distress

Impact of 1 percentage point increase in US bank distress on industrial production

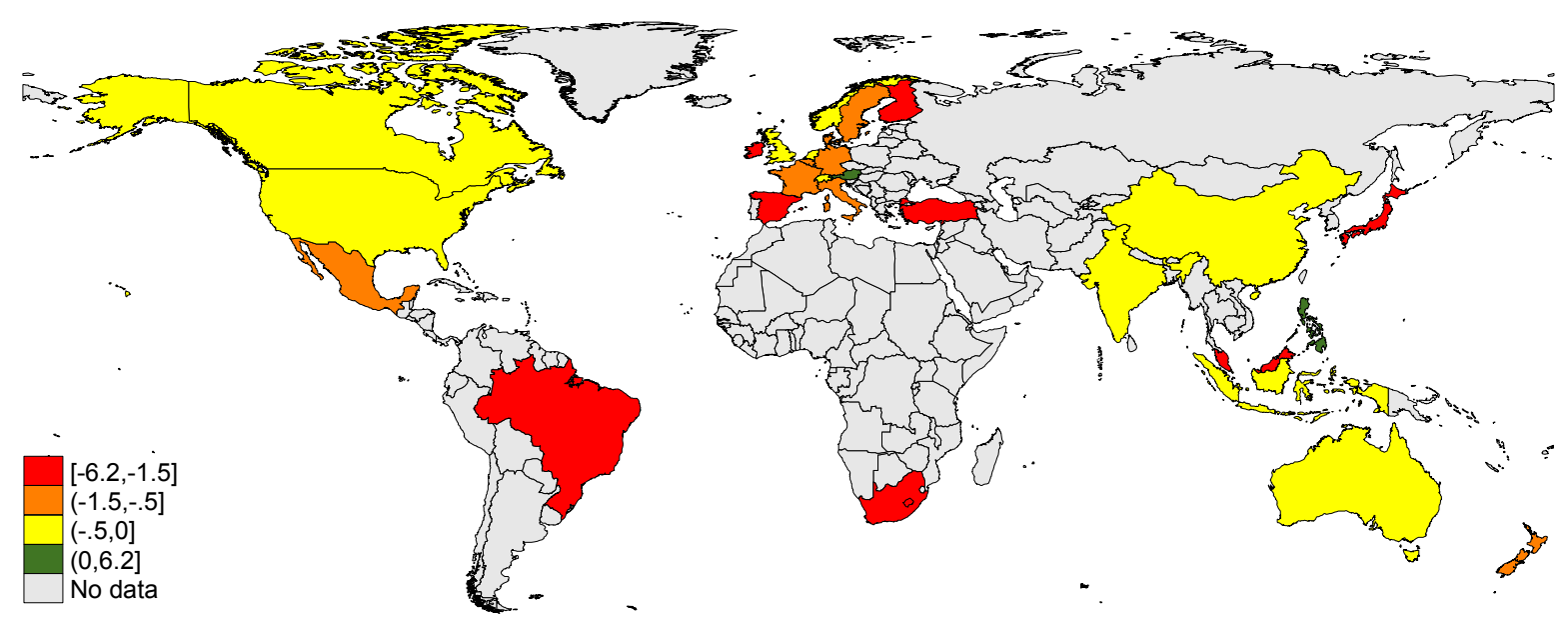

Impact of 1 percentage point increase in US corporate distress on industrial production

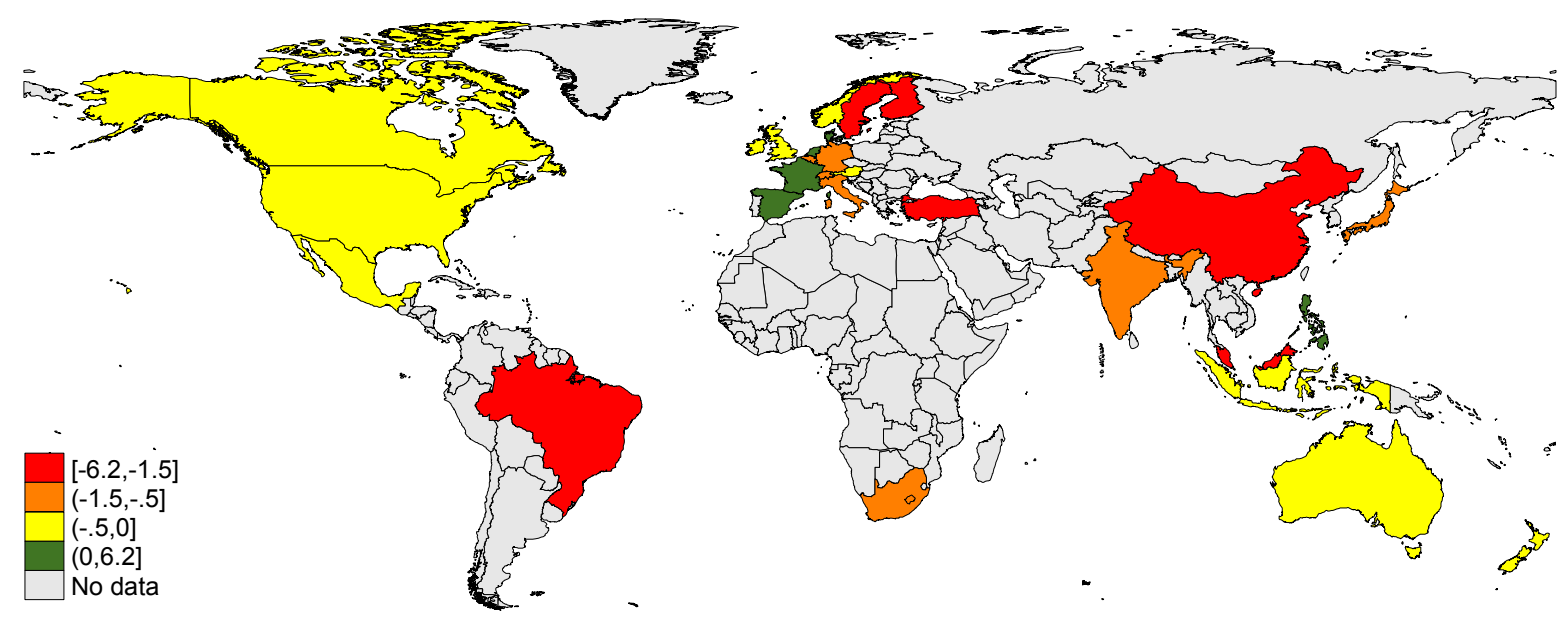


Figure 13. Impact of One Percentage Point Decline in the U.S. Industrial Production (In percentage points)

\section{On the United States}
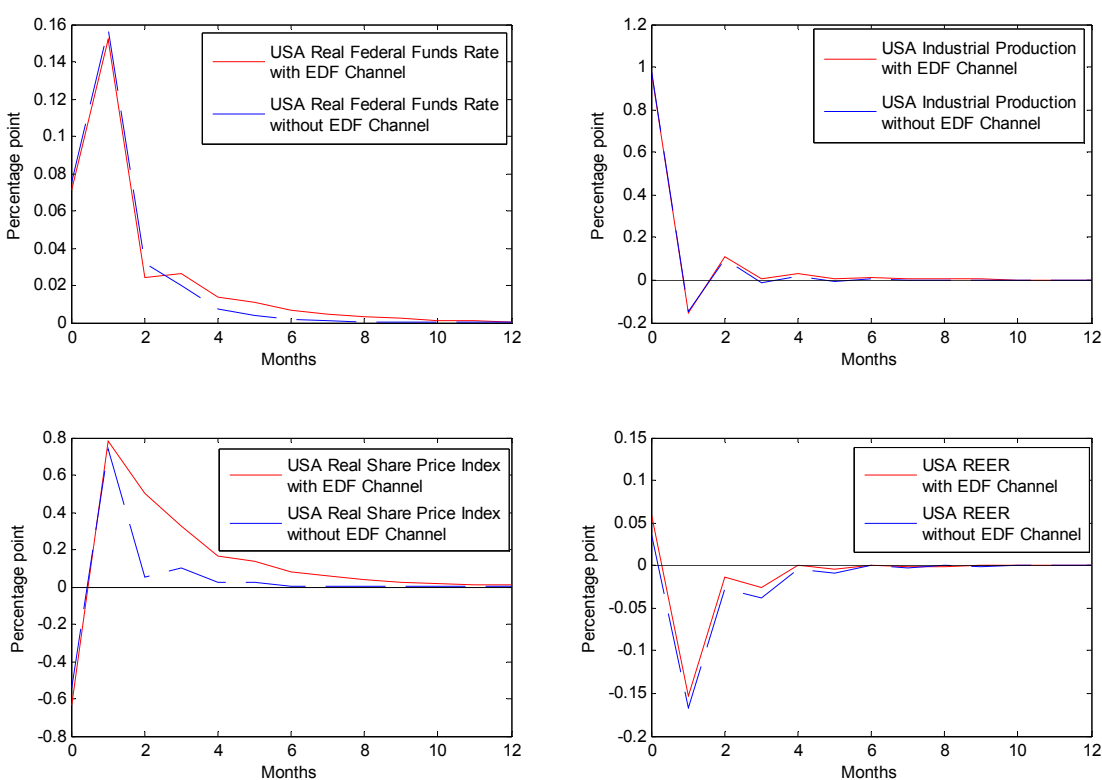

On Germany
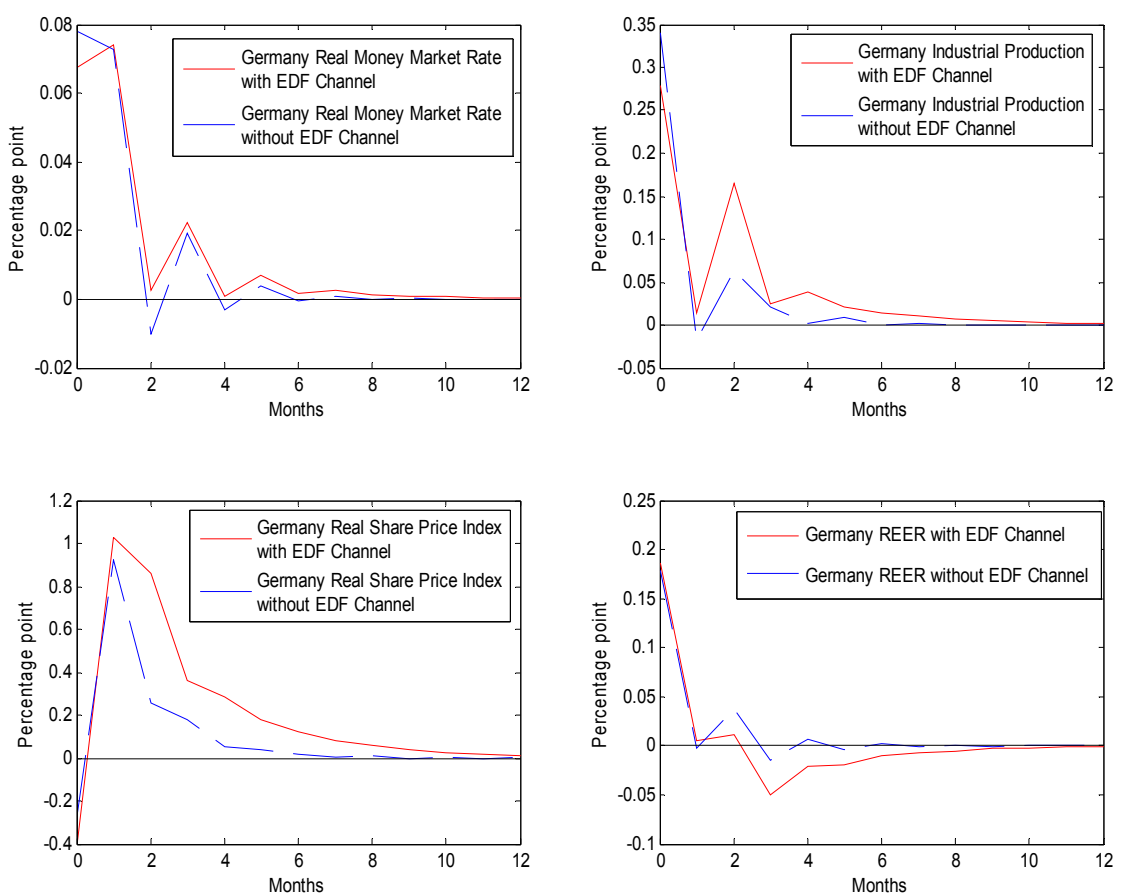

Source: Authors' estimates. 
Table 1. Financial Weights

\begin{tabular}{|c|c|c|c|c|c|c|c|c|c|c|c|c|c|c|c|c|}
\hline & Australia & Austria & Belgium & Brazil & Canada & China & Denmark & Finland & France & Germany & Hong Kong & India & Indonesia & Ireland & Italy & Japan \\
\hline Australia & $0.0 \%$ & $0.0 \%$ & $0.2 \%$ & $0.1 \%$ & $0.8 \%$ & $0.1 \%$ & $0.1 \%$ & $0.1 \%$ & $1.6 \%$ & $5.5 \%$ & $2.1 \%$ & $4.9 \%$ & $0.2 \%$ & $0.0 \%$ & $1.5 \%$ & $0.1 \%$ \\
\hline Austria & $0.4 \%$ & $0.0 \%$ & $1.2 \%$ & $0.1 \%$ & $0.4 \%$ & $0.1 \%$ & $0.3 \%$ & $0.1 \%$ & $5.0 \%$ & $33.9 \%$ & $0.2 \%$ & $3.1 \%$ & $0.0 \%$ & $0.5 \%$ & $5.9 \%$ & $0.0 \%$ \\
\hline Brazil & $0.1 \%$ & $0.1 \%$ & $0.5 \%$ & $0.0 \%$ & $1.0 \%$ & $0.1 \%$ & $0.1 \%$ & $0.0 \%$ & $2.2 \%$ & $5.4 \%$ & $0.0 \%$ & $1.7 \%$ & $0.0 \%$ & $0.5 \%$ & $2.6 \%$ & $0.0 \%$ \\
\hline Canada & $1.3 \%$ & $0.2 \%$ & $0.7 \%$ & $1.0 \%$ & $0.0 \%$ & $0.1 \%$ & $0.2 \%$ & $0.2 \%$ & $2.9 \%$ & $5.2 \%$ & $1.1 \%$ & $4.6 \%$ & $0.5 \%$ & $1.5 \%$ & $1.9 \%$ & $0.1 \%$ \\
\hline China & $0.2 \%$ & $0.0 \%$ & $0.4 \%$ & $0.0 \%$ & $0.1 \%$ & $0.0 \%$ & $0.0 \%$ & $0.0 \%$ & $1.6 \%$ & $5.6 \%$ & $12.4 \%$ & $6.6 \%$ & $0.0 \%$ & $0.0 \%$ & $2.2 \%$ & $0.1 \%$ \\
\hline Denmark & $0.9 \%$ & $0.5 \%$ & $0.5 \%$ & $0.3 \%$ & $0.8 \%$ & $0.3 \%$ & $0.0 \%$ & $1.0 \%$ & $4.0 \%$ & $13.1 \%$ & $0.4 \%$ & $3.2 \%$ & $0.0 \%$ & $0.6 \%$ & $2.8 \%$ & $0.1 \%$ \\
\hline Finland & $0.3 \%$ & $0.6 \%$ & $2.9 \%$ & $0.1 \%$ & $0.4 \%$ & $0.3 \%$ & $1.8 \%$ & $0.0 \%$ & $4.8 \%$ & $14.0 \%$ & $0.2 \%$ & $2.9 \%$ & $0.0 \%$ & $0.7 \%$ & $2.9 \%$ & $0.1 \%$ \\
\hline France & $0.4 \%$ & $0.4 \%$ & $9.0 \%$ & $0.8 \%$ & $2.1 \%$ & $0.2 \%$ & $0.2 \%$ & $0.1 \%$ & $0.0 \%$ & $14.1 \%$ & $0.2 \%$ & $3.0 \%$ & $0.1 \%$ & $1.0 \%$ & $6.3 \%$ & $0.1 \%$ \\
\hline Germany & $0.5 \%$ & $2.0 \%$ & $3.5 \%$ & $0.4 \%$ & $0.4 \%$ & $0.4 \%$ & $0.3 \%$ & $0.3 \%$ & $12.1 \%$ & $0.0 \%$ & $0.3 \%$ & $3.9 \%$ & $0.1 \%$ & $1.8 \%$ & $6.5 \%$ & $0.1 \%$ \\
\hline Hong Kong & $0.9 \%$ & $0.0 \%$ & $0.4 \%$ & $0.0 \%$ & $0.6 \%$ & $25.4 \%$ & $0.0 \%$ & $0.0 \%$ & $1.6 \%$ & $6.6 \%$ & $0.0 \%$ & $4.9 \%$ & $0.0 \%$ & $0.1 \%$ & $2.2 \%$ & $0.0 \%$ \\
\hline India & $2.5 \%$ & $0.0 \%$ & $0.8 \%$ & $0.2 \%$ & $1.1 \%$ & $0.7 \%$ & $0.2 \%$ & $0.0 \%$ & $3.4 \%$ & $12.9 \%$ & $0.5 \%$ & $0.0 \%$ & $0.4 \%$ & $0.1 \%$ & $4.5 \%$ & $0.1 \%$ \\
\hline Indonesia & $0.2 \%$ & $0.0 \%$ & $0.3 \%$ & $0.0 \%$ & $0.0 \%$ & $1.9 \%$ & $0.0 \%$ & $0.0 \%$ & $1.2 \%$ & $10.7 \%$ & $1.4 \%$ & $14.4 \%$ & $0.0 \%$ & $0.0 \%$ & $1.5 \%$ & $0.0 \%$ \\
\hline Ireland & $0.4 \%$ & $0.2 \%$ & $0.9 \%$ & $0.1 \%$ & $0.2 \%$ & $0.0 \%$ & $0.1 \%$ & $0.2 \%$ & $6.1 \%$ & $16.2 \%$ & $0.4 \%$ & $4.2 \%$ & $0.0 \%$ & $0.0 \%$ & $6.1 \%$ & $0.1 \%$ \\
\hline Italy & $0.4 \%$ & $0.5 \%$ & $2.1 \%$ & $1.2 \%$ & $0.5 \%$ & $0.1 \%$ & $0.1 \%$ & $0.1 \%$ & $11.3 \%$ & $14.7 \%$ & $0.2 \%$ & $4.0 \%$ & $0.0 \%$ & $0.7 \%$ & $0.0 \%$ & $0.0 \%$ \\
\hline Japan & $0.0 \%$ & $0.0 \%$ & $0.5 \%$ & $0.0 \%$ & $0.0 \%$ & $0.2 \%$ & $0.0 \%$ & $0.0 \%$ & $1.4 \%$ & $9.5 \%$ & $0.0 \%$ & $3.2 \%$ & $0.2 \%$ & $0.0 \%$ & $2.1 \%$ & $0.0 \%$ \\
\hline Mexico & $0.1 \%$ & $0.0 \%$ & $0.2 \%$ & $0.3 \%$ & $0.2 \%$ & $0.1 \%$ & $0.0 \%$ & $0.0 \%$ & $1.0 \%$ & $2.3 \%$ & $0.1 \%$ & $1.3 \%$ & $0.0 \%$ & $0.0 \%$ & $0.9 \%$ & $0.1 \%$ \\
\hline Netherlands & $0.9 \%$ & $0.6 \%$ & $8.6 \%$ & $0.7 \%$ & $1.1 \%$ & $0.2 \%$ & $0.4 \%$ & $0.3 \%$ & $8.5 \%$ & $16.4 \%$ & $0.9 \%$ & $2.8 \%$ & $0.1 \%$ & $1.8 \%$ & $3.9 \%$ & $0.1 \%$ \\
\hline New Zealand & $22.4 \%$ & $0.0 \%$ & $0.2 \%$ & $0.0 \%$ & $5.0 \%$ & $0.1 \%$ & $0.1 \%$ & $0.1 \%$ & $2.0 \%$ & $6.2 \%$ & $0.8 \%$ & $5.4 \%$ & $0.4 \%$ & $0.5 \%$ & $1.1 \%$ & $0.0 \%$ \\
\hline Norway & $0.9 \%$ & $0.3 \%$ & $1.3 \%$ & $0.2 \%$ & $1.9 \%$ & $0.0 \%$ & $3.0 \%$ & $1.6 \%$ & $3.0 \%$ & $10.9 \%$ & $0.2 \%$ & $3.3 \%$ & $0.0 \%$ & $0.4 \%$ & $1.4 \%$ & $0.0 \%$ \\
\hline Philippines & $0.9 \%$ & $0.0 \%$ & $0.3 \%$ & $0.0 \%$ & $0.0 \%$ & $2.6 \%$ & $0.0 \%$ & $0.0 \%$ & $1.6 \%$ & $5.1 \%$ & $2.0 \%$ & $6.1 \%$ & $0.1 \%$ & $0.1 \%$ & $1.6 \%$ & $0.1 \%$ \\
\hline Singapore & $1.9 \%$ & $0.0 \%$ & $0.4 \%$ & $0.0 \%$ & $0.2 \%$ & $4.5 \%$ & $0.0 \%$ & $0.0 \%$ & $1.4 \%$ & $5.7 \%$ & $5.9 \%$ & $5.4 \%$ & $2.2 \%$ & $0.0 \%$ & $2.0 \%$ & $0.4 \%$ \\
\hline South Africa & $1.0 \%$ & $0.1 \%$ & $0.6 \%$ & $0.2 \%$ & $0.1 \%$ & $0.1 \%$ & $0.0 \%$ & $0.6 \%$ & $2.5 \%$ & $5.2 \%$ & $0.6 \%$ & $1.3 \%$ & $0.1 \%$ & $1.8 \%$ & $1.6 \%$ & $0.2 \%$ \\
\hline Spain & $0.0 \%$ & $0.4 \%$ & $0.7 \%$ & $7.1 \%$ & $0.3 \%$ & $0.2 \%$ & $0.3 \%$ & $0.1 \%$ & $10.0 \%$ & $26.0 \%$ & $0.0 \%$ & $2.9 \%$ & $0.1 \%$ & $0.2 \%$ & $4.3 \%$ & $0.2 \%$ \\
\hline Sweden & $0.7 \%$ & $0.7 \%$ & $0.2 \%$ & $0.7 \%$ & $0.9 \%$ & $0.3 \%$ & $3.9 \%$ & $5.3 \%$ & $4.6 \%$ & $8.7 \%$ & $0.2 \%$ & $3.0 \%$ & $0.0 \%$ & $2.0 \%$ & $2.4 \%$ & $0.0 \%$ \\
\hline Switzerland & $0.9 \%$ & $0.5 \%$ & $1.4 \%$ & $0.4 \%$ & $1.1 \%$ & $0.1 \%$ & $0.2 \%$ & $0.3 \%$ & $6.2 \%$ & $12.1 \%$ & $0.4 \%$ & $3.9 \%$ & $0.1 \%$ & $0.8 \%$ & $3.7 \%$ & $0.1 \%$ \\
\hline Turkey & $0.0 \%$ & $0.0 \%$ & $0.1 \%$ & $0.0 \%$ & $0.1 \%$ & $0.0 \%$ & $0.0 \%$ & $0.1 \%$ & $0.4 \%$ & $25.6 \%$ & $0.0 \%$ & $4.0 \%$ & $0.0 \%$ & $0.2 \%$ & $0.1 \%$ & $0.0 \%$ \\
\hline United Kingdom & $1.4 \%$ & $0.1 \%$ & $1.1 \%$ & $0.2 \%$ & $0.8 \%$ & $0.1 \%$ & $0.3 \%$ & $0.2 \%$ & $5.3 \%$ & $12.1 \%$ & $1.0 \%$ & $5.7 \%$ & $0.1 \%$ & $1.0 \%$ & $4.7 \%$ & $0.1 \%$ \\
\hline United States & $2.8 \%$ & $0.4 \%$ & $1.6 \%$ & $2.3 \%$ & $9.8 \%$ & $0.6 \%$ & $0.5 \%$ & $0.8 \%$ & $6.2 \%$ & $8.7 \%$ & $2.2 \%$ & $10.7 \%$ & $0.5 \%$ & $1.9 \%$ & $3.4 \%$ & $0.5 \%$ \\
\hline
\end{tabular}

Note: The table reports currency exposure measures constructed by Lane and Shambaugh (2009) for bilateral financial asset positions in five instruments: portfolio equity, direct investment, portfolio debt, other general bank-related debt, and reserves. We take the average weight from 1999 to 2004 (the latest data for which Lane and Shambaugh's data are available) as a fixed weight for the four financial variables in the model. The financial weights for the euro area countries are computed by multiplying the weight for the euro area with the share of the country in the euro area weight for 1998. 
Table 1. Financial Weights, continued

Malaysia Mexico Netherlands New Zealand Norway Philippines Singapore South Africa Spain Sweden Switzerland Turkey United Kingdom United States

\begin{tabular}{|c|c|c|c|c|c|c|c|c|c|c|c|c|c|c|}
\hline Australia & $0.2 \%$ & $0.0 \%$ & $1.8 \%$ & $5.4 \%$ & $0.1 \%$ & $0.0 \%$ & $0.5 \%$ & $0.1 \%$ & $0.2 \%$ & $0.2 \%$ & $1.0 \%$ & $0.0 \%$ & $16.9 \%$ & $56.2 \%$ \\
\hline Austria & $0.0 \%$ & $0.0 \%$ & $4.6 \%$ & $0.0 \%$ & $0.0 \%$ & $0.0 \%$ & $0.1 \%$ & $0.0 \%$ & $0.5 \%$ & $0.5 \%$ & $3.8 \%$ & $0.0 \%$ & $5.9 \%$ & $33.2 \%$ \\
\hline Belgium & $0.0 \%$ & $0.0 \%$ & $18.2 \%$ & $0.0 \%$ & $0.0 \%$ & $0.0 \%$ & $0.0 \%$ & $0.1 \%$ & $1.4 \%$ & $0.9 \%$ & $2.4 \%$ & $0.1 \%$ & $4.8 \%$ & $24.0 \%$ \\
\hline Brazil & $0.0 \%$ & $0.3 \%$ & $3.8 \%$ & $0.0 \%$ & $0.1 \%$ & $0.0 \%$ & $0.0 \%$ & $0.0 \%$ & $9.3 \%$ & $0.0 \%$ & $1.4 \%$ & $0.0 \%$ & $3.0 \%$ & $67.7 \%$ \\
\hline Canada & $0.1 \%$ & $0.6 \%$ & $2.2 \%$ & $0.2 \%$ & $0.2 \%$ & $0.1 \%$ & $0.6 \%$ & $0.1 \%$ & $0.6 \%$ & $0.5 \%$ & $1.9 \%$ & $0.1 \%$ & $9.7 \%$ & $61.8 \%$ \\
\hline China & $0.0 \%$ & $0.0 \%$ & $0.8 \%$ & $0.0 \%$ & $0.0 \%$ & $0.0 \%$ & $0.0 \%$ & $0.0 \%$ & $0.1 \%$ & $0.0 \%$ & $0.9 \%$ & $0.0 \%$ & $2.3 \%$ & $66.5 \%$ \\
\hline Denmark & $0.2 \%$ & $0.1 \%$ & $5.8 \%$ & $0.1 \%$ & $2.1 \%$ & $0.0 \%$ & $0.2 \%$ & $0.1 \%$ & $0.8 \%$ & $6.8 \%$ & $4.2 \%$ & $0.0 \%$ & $10.0 \%$ & $40.8 \%$ \\
\hline Finland & $0.0 \%$ & $0.0 \%$ & $11.3 \%$ & $0.0 \%$ & $2.4 \%$ & $0.0 \%$ & $0.2 \%$ & $0.0 \%$ & $0.8 \%$ & $14.5 \%$ & $3.4 \%$ & $0.0 \%$ & $9.8 \%$ & $25.5 \%$ \\
\hline France & $0.0 \%$ & $0.1 \%$ & $11.2 \%$ & $0.0 \%$ & $0.1 \%$ & $0.0 \%$ & $0.4 \%$ & $0.0 \%$ & $4.6 \%$ & $0.6 \%$ & $3.9 \%$ & $0.1 \%$ & $10.7 \%$ & $30.2 \%$ \\
\hline Germany & $0.1 \%$ & $0.3 \%$ & $5.8 \%$ & $0.1 \%$ & $0.2 \%$ & $0.0 \%$ & $0.3 \%$ & $0.2 \%$ & $2.1 \%$ & $0.8 \%$ & $4.2 \%$ & $0.2 \%$ & $10.1 \%$ & $43.0 \%$ \\
\hline Hong Kong & $0.6 \%$ & $0.0 \%$ & $1.1 \%$ & $0.9 \%$ & $0.0 \%$ & $0.2 \%$ & $1.1 \%$ & $0.0 \%$ & $0.1 \%$ & $0.1 \%$ & $1.4 \%$ & $0.0 \%$ & $9.9 \%$ & $41.9 \%$ \\
\hline India & $0.2 \%$ & $0.1 \%$ & $2.5 \%$ & $0.0 \%$ & $0.0 \%$ & $0.1 \%$ & $0.5 \%$ & $0.0 \%$ & $0.2 \%$ & $0.4 \%$ & $1.6 \%$ & $0.0 \%$ & $6.0 \%$ & $60.8 \%$ \\
\hline Indonesia & $0.0 \%$ & $0.0 \%$ & $1.7 \%$ & $0.0 \%$ & $0.0 \%$ & $0.0 \%$ & $2.5 \%$ & $0.0 \%$ & $0.0 \%$ & $0.0 \%$ & $0.9 \%$ & $0.0 \%$ & $5.2 \%$ & $58.0 \%$ \\
\hline Ireland & $0.0 \%$ & $0.1 \%$ & $4.3 \%$ & $0.0 \%$ & $0.1 \%$ & $0.0 \%$ & $0.1 \%$ & $0.1 \%$ & $1.1 \%$ & $0.3 \%$ & $2.4 \%$ & $0.0 \%$ & $16.8 \%$ & $39.5 \%$ \\
\hline Italy & $0.0 \%$ & $0.1 \%$ & $12.8 \%$ & $0.1 \%$ & $0.0 \%$ & $0.0 \%$ & $0.1 \%$ & $0.1 \%$ & $5.1 \%$ & $0.4 \%$ & $5.1 \%$ & $0.1 \%$ & $9.5 \%$ & $30.4 \%$ \\
\hline Japan & $0.8 \%$ & $0.0 \%$ & $0.8 \%$ & $0.0 \%$ & $0.0 \%$ & $0.0 \%$ & $0.7 \%$ & $0.0 \%$ & $0.0 \%$ & $0.0 \%$ & $1.1 \%$ & $0.0 \%$ & $7.6 \%$ & $71.6 \%$ \\
\hline Malaysia & $0.0 \%$ & $0.0 \%$ & $1.5 \%$ & $0.1 \%$ & $0.0 \%$ & $0.6 \%$ & $6.6 \%$ & $0.5 \%$ & $0.0 \%$ & $0.0 \%$ & $0.9 \%$ & $0.0 \%$ & $5.6 \%$ & $57.9 \%$ \\
\hline Mexico & $0.1 \%$ & $0.0 \%$ & $0.4 \%$ & $0.0 \%$ & $0.0 \%$ & $0.0 \%$ & $0.0 \%$ & $0.1 \%$ & $0.5 \%$ & $0.0 \%$ & $0.8 \%$ & $0.0 \%$ & $1.6 \%$ & $89.9 \%$ \\
\hline Netherlands & $0.1 \%$ & $0.3 \%$ & $0.0 \%$ & $0.1 \%$ & $0.3 \%$ & $0.1 \%$ & $0.5 \%$ & $0.1 \%$ & $3.0 \%$ & $0.8 \%$ & $4.6 \%$ & $0.1 \%$ & $9.9 \%$ & $32.7 \%$ \\
\hline New Zealand & $0.2 \%$ & $0.0 \%$ & $1.1 \%$ & $0.0 \%$ & $0.0 \%$ & $0.0 \%$ & $0.5 \%$ & $0.0 \%$ & $0.3 \%$ & $0.2 \%$ & $1.0 \%$ & $0.0 \%$ & $10.1 \%$ & $42.3 \%$ \\
\hline Norway & $0.1 \%$ & $0.1 \%$ & $2.9 \%$ & $0.1 \%$ & $0.0 \%$ & $0.0 \%$ & $0.6 \%$ & $0.1 \%$ & $0.4 \%$ & $5.8 \%$ & $2.7 \%$ & $0.0 \%$ & $13.6 \%$ & $45.0 \%$ \\
\hline Philippines & $0.1 \%$ & $0.0 \%$ & $0.7 \%$ & $0.0 \%$ & $0.0 \%$ & $0.0 \%$ & $1.3 \%$ & $0.0 \%$ & $0.1 \%$ & $0.0 \%$ & $1.0 \%$ & $0.0 \%$ & $3.1 \%$ & $73.3 \%$ \\
\hline Singapore & $7.2 \%$ & $0.0 \%$ & $1.6 \%$ & $0.3 \%$ & $0.0 \%$ & $0.8 \%$ & $0.0 \%$ & $0.0 \%$ & $0.0 \%$ & $0.1 \%$ & $1.4 \%$ & $0.0 \%$ & $7.0 \%$ & $51.4 \%$ \\
\hline South Africa & $0.3 \%$ & $0.2 \%$ & $3.6 \%$ & $0.0 \%$ & $0.0 \%$ & $0.1 \%$ & $0.2 \%$ & $0.0 \%$ & $0.9 \%$ & $0.1 \%$ & $7.8 \%$ & $0.1 \%$ & $42.8 \%$ & $27.8 \%$ \\
\hline Spain & $0.0 \%$ & $0.1 \%$ & $2.8 \%$ & $0.0 \%$ & $0.0 \%$ & $0.0 \%$ & $0.0 \%$ & $0.0 \%$ & $0.0 \%$ & $0.1 \%$ & $2.2 \%$ & $0.2 \%$ & $9.1 \%$ & $32.6 \%$ \\
\hline Sweden & $0.0 \%$ & $0.3 \%$ & $9.2 \%$ & $0.0 \%$ & $4.0 \%$ & $0.0 \%$ & $0.4 \%$ & $0.0 \%$ & $1.1 \%$ & $0.0 \%$ & $4.3 \%$ & $0.0 \%$ & $11.8 \%$ & $35.1 \%$ \\
\hline Switzerland & $0.1 \%$ & $0.3 \%$ & $3.7 \%$ & $0.1 \%$ & $0.2 \%$ & $0.1 \%$ & $0.8 \%$ & $0.1 \%$ & $0.8 \%$ & $0.5 \%$ & $0.0 \%$ & $0.1 \%$ & $10.6 \%$ & $50.7 \%$ \\
\hline Turkey & $0.0 \%$ & $0.0 \%$ & $2.6 \%$ & $0.0 \%$ & $0.0 \%$ & $0.0 \%$ & $0.0 \%$ & $0.0 \%$ & $0.1 \%$ & $0.0 \%$ & $1.9 \%$ & $0.0 \%$ & $4.2 \%$ & $60.5 \%$ \\
\hline United Kingdom & $0.1 \%$ & $0.2 \%$ & $5.6 \%$ & $0.1 \%$ & $0.3 \%$ & $0.0 \%$ & $0.4 \%$ & $0.4 \%$ & $1.5 \%$ & $0.9 \%$ & $3.4 \%$ & $0.0 \%$ & $0.0 \%$ & $52.8 \%$ \\
\hline United States & $0.4 \%$ & $2.9 \%$ & $9.7 \%$ & $0.3 \%$ & $0.6 \%$ & $0.3 \%$ & $2.1 \%$ & $0.5 \%$ & $2.0 \%$ & $1.8 \%$ & $5.5 \%$ & $0.2 \%$ & $20.9 \%$ & $0.0 \%$ \\
\hline
\end{tabular}

Note: The table reports currency exposure measures constructed by Lane and Shambaugh (2009) for bilateral financial asset positions in five instruments: portfolio equity, direct investment, portfolio debt, other general bank-related debt, and reserves. We take the average weight from 1999 to 2004 (the latest data for which Lane and Shambaugh's data are available) as a fixed weight for the four financial variables in the model. The financial weights for the euro area countries are computed by multiplying the weight for the euro area with the share of the country in the euro area weight for 1998. 
Table 2. Trade Weights

\begin{tabular}{|c|c|c|c|c|c|c|c|c|c|c|c|c|c|c|c|c|}
\hline & Australia & Austria & Belgium & Brazil & Canada & China & Denmark & Finland & France & Germany & Hong Kong & India & Indonesia & Ireland & Italy & Japan \\
\hline Brazil & $0.9 \%$ & $0.5 \%$ & $1.2 \%$ & $0.0 \%$ & $2.4 \%$ & $9.9 \%$ & $0.4 \%$ & $0.7 \%$ & $4.4 \%$ & $9.9 \%$ & $1.1 \%$ & $1.5 \%$ & $0.8 \%$ & $0.4 \%$ & $5.3 \%$ & $6.6 \%$ \\
\hline China & $2.8 \%$ & $0.3 \%$ & $1.2 \%$ & $1.8 \%$ & $2.0 \%$ & $0.0 \%$ & $0.4 \%$ & $0.7 \%$ & $2.3 \%$ & $6.6 \%$ & $15.1 \%$ & $2.0 \%$ & $1.8 \%$ & $0.4 \%$ & $2.1 \%$ & $19.8 \%$ \\
\hline France & $0.5 \%$ & $1.2 \%$ & $9.4 \%$ & $0.9 \%$ & $0.8 \%$ & $2.9 \%$ & $1.0 \%$ & $0.7 \%$ & $0.0 \%$ & $21.2 \%$ & $0.6 \%$ & $0.6 \%$ & $0.3 \%$ & $1.4 \%$ & $11.2 \%$ & $2.2 \%$ \\
\hline Germany & $0.6 \%$ & $6.2 \%$ & $6.2 \%$ & $1.0 \%$ & $0.8 \%$ & $4.7 \%$ & $2.1 \%$ & $1.3 \%$ & $12.8 \%$ & $0.0 \%$ & $0.6 \%$ & $0.7 \%$ & $0.4 \%$ & $1.4 \%$ & $8.8 \%$ & $3.3 \%$ \\
\hline India & $4.2 \%$ & $0.3 \%$ & $1.0 \%$ & $0.9 \%$ & $2.3 \%$ & $0.9 \%$ & $0.4 \%$ & $0.4 \%$ & $2.0 \%$ & $4.7 \%$ & $4.4 \%$ & $0.0 \%$ & $3.6 \%$ & $0.7 \%$ & $1.6 \%$ & $7.7 \%$ \\
\hline Japan & $4.0 \%$ & $0.4 \%$ & $5.9 \%$ & $1.3 \%$ & $1.7 \%$ & $2.1 \%$ & $0.5 \%$ & $0.4 \%$ & $3.2 \%$ & $7.0 \%$ & $4.9 \%$ & $12.3 \%$ & $3.1 \%$ & $0.3 \%$ & $3.5 \%$ & $0.0 \%$ \\
\hline United Kingdom & $1.2 \%$ & $0.8 \%$ & $4.9 \%$ & $0.7 \%$ & $2.0 \%$ & $3.4 \%$ & $1.4 \%$ & $1.1 \%$ & $10.0 \%$ & $14.8 \%$ & $2.2 \%$ & $1.3 \%$ & $0.4 \%$ & $6.1 \%$ & $5.2 \%$ & $3.5 \%$ \\
\hline Australia & $0.0 \%$ & $0.4 \%$ & $0.6 \%$ & $0.6 \%$ & $1.7 \%$ & $13.8 \%$ & $0.4 \%$ & $0.7 \%$ & $2.3 \%$ & $4.5 \%$ & $2.1 \%$ & $2.8 \%$ & $3.4 \%$ & $0.8 \%$ & $2.7 \%$ & $19.4 \%$ \\
\hline Austria & $0.4 \%$ & $0.0 \%$ & $2.1 \%$ & $0.4 \%$ & $0.7 \%$ & $1.9 \%$ & $0.8 \%$ & $0.8 \%$ & $5.0 \%$ & $48.9 \%$ & $0.4 \%$ & $0.3 \%$ & $0.2 \%$ & $0.5 \%$ & $10.2 \%$ & $1.5 \%$ \\
\hline Belgium & $0.4 \%$ & $1.0 \%$ & $0.0 \%$ & $0.7 \%$ & $0.7 \%$ & $2.2 \%$ & $0.7 \%$ & $0.7 \%$ & $17.0 \%$ & $21.1 \%$ & $0.6 \%$ & $1.5 \%$ & $0.3 \%$ & $3.0 \%$ & $5.1 \%$ & $2.1 \%$ \\
\hline Canada & $0.4 \%$ & $0.2 \%$ & $0.5 \%$ & $0.5 \%$ & $0.0 \%$ & $4.0 \%$ & $0.2 \%$ & $0.2 \%$ & $1.1 \%$ & $1.8 \%$ & $0.3 \%$ & $0.4 \%$ & $0.2 \%$ & $0.3 \%$ & $0.9 \%$ & $3.4 \%$ \\
\hline Switzerland & $0.6 \%$ & $4.1 \%$ & $2.3 \%$ & $0.8 \%$ & $0.9 \%$ & $2.1 \%$ & $0.9 \%$ & $0.7 \%$ & $11.0 \%$ & $29.8 \%$ & $2.0 \%$ & $0.7 \%$ & $0.2 \%$ & $1.8 \%$ & $10.7 \%$ & $3.4 \%$ \\
\hline Denmark & $0.5 \%$ & $1.2 \%$ & $2.5 \%$ & $0.4 \%$ & $0.7 \%$ & $2.9 \%$ & $0.0 \%$ & $3.1 \%$ & $5.8 \%$ & $23.6 \%$ & $0.8 \%$ & $0.5 \%$ & $0.2 \%$ & $1.4 \%$ & $4.5 \%$ & $2.3 \%$ \\
\hline Spain & $0.5 \%$ & $1.2 \%$ & $4.2 \%$ & $1.2 \%$ & $0.5 \%$ & $3.6 \%$ & $1.0 \%$ & $0.8 \%$ & $22.5 \%$ & $18.8 \%$ & $0.3 \%$ & $0.6 \%$ & $0.6 \%$ & $1.4 \%$ & $11.7 \%$ & $2.1 \%$ \\
\hline Finland & $1.2 \%$ & $1.3 \%$ & $3.0 \%$ & $0.9 \%$ & $1.0 \%$ & $4.4 \%$ & $4.4 \%$ & $0.0 \%$ & $5.3 \%$ & $17.9 \%$ & $0.8 \%$ & $0.6 \%$ & $0.4 \%$ & $0.9 \%$ & $4.5 \%$ & $3.1 \%$ \\
\hline Hong Kong & $1.1 \%$ & $0.2 \%$ & $0.7 \%$ & $0.4 \%$ & $1.0 \%$ & $49.5 \%$ & $0.3 \%$ & $0.3 \%$ & $1.4 \%$ & $3.1 \%$ & $0.0 \%$ & $1.3 \%$ & $0.7 \%$ & $0.2 \%$ & $1.4 \%$ & $9.7 \%$ \\
\hline Indonesia & $4.8 \%$ & $0.2 \%$ & $1.0 \%$ & $0.9 \%$ & $1.2 \%$ & $9.7 \%$ & $0.2 \%$ & $0.4 \%$ & $1.6 \%$ & $3.8 \%$ & $2.2 \%$ & $3.4 \%$ & $0.0 \%$ & $0.2 \%$ & $1.7 \%$ & $24.1 \%$ \\
\hline Ireland & $0.6 \%$ & $0.4 \%$ & $7.8 \%$ & $0.2 \%$ & $0.6 \%$ & $1.5 \%$ & $1.0 \%$ & $0.5 \%$ & $6.1 \%$ & $9.7 \%$ & $0.7 \%$ & $0.2 \%$ & $0.1 \%$ & $0.0 \%$ & $3.5 \%$ & $3.2 \%$ \\
\hline Italy & $0.8 \%$ & $3.3 \%$ & $4.0 \%$ & $1.3 \%$ & $0.9 \%$ & $3.8 \%$ & $1.0 \%$ & $0.8 \%$ & $15.7 \%$ & $21.8 \%$ & $0.9 \%$ & $0.9 \%$ & $0.4 \%$ & $1.1 \%$ & $0.0 \%$ & $2.3 \%$ \\
\hline Mexico & $0.2 \%$ & $0.1 \%$ & $0.1 \%$ & $1.2 \%$ & $2.5 \%$ & $3.8 \%$ & $0.1 \%$ & $0.1 \%$ & $0.7 \%$ & $2.7 \%$ & $0.2 \%$ & $0.3 \%$ & $0.2 \%$ & $0.2 \%$ & $0.9 \%$ & $3.3 \%$ \\
\hline Malaysia & $3.1 \%$ & $0.2 \%$ & $0.6 \%$ & $0.5 \%$ & $0.8 \%$ & $9.3 \%$ & $0.2 \%$ & $0.3 \%$ & $1.7 \%$ & $3.9 \%$ & $4.9 \%$ & $2.3 \%$ & $3.5 \%$ & $0.7 \%$ & $0.9 \%$ & $16.6 \%$ \\
\hline Netherlands & $0.4 \%$ & $1.3 \%$ & $12.1 \%$ & $1.0 \%$ & $0.6 \%$ & $4.6 \%$ & $1.5 \%$ & $1.2 \%$ & $9.1 \%$ & $26.6 \%$ & $0.7 \%$ & $0.5 \%$ & $0.5 \%$ & $1.3 \%$ & $5.0 \%$ & $2.6 \%$ \\
\hline Norward & $0.2 \%$ & $0.6 \%$ & $2.6 \%$ & $0.6 \%$ & $3.6 \%$ & $2.6 \%$ & $5.6 \%$ & $2.6 \%$ & $8.2 \%$ & $14.1 \%$ & $0.3 \%$ & $0.3 \%$ & $0.1 \%$ & $1.5 \%$ & $3.4 \%$ & $2.2 \%$ \\
\hline New Zealand & $26.1 \%$ & $0.3 \%$ & $1.4 \%$ & $0.4 \%$ & $1.9 \%$ & $8.7 \%$ & $0.6 \%$ & $0.4 \%$ & $2.1 \%$ & $4.4 \%$ & $1.5 \%$ & $0.8 \%$ & $2.0 \%$ & $0.4 \%$ & $2.3 \%$ & $13.5 \%$ \\
\hline Philippines & $1.8 \%$ & $0.1 \%$ & $0.8 \%$ & $0.4 \%$ & $0.9 \%$ & $7.4 \%$ & $0.1 \%$ & $0.3 \%$ & $1.2 \%$ & $4.0 \%$ & $7.1 \%$ & $0.7 \%$ & $1.9 \%$ & $0.9 \%$ & $0.6 \%$ & $21.4 \%$ \\
\hline Singapore & $3.2 \%$ & $0.2 \%$ & $0.6 \%$ & $0.4 \%$ & $0.5 \%$ & $10.1 \%$ & $0.2 \%$ & $0.3 \%$ & $2.5 \%$ & $3.8 \%$ & $7.7 \%$ & $2.7 \%$ & $6.5 \%$ & $0.8 \%$ & $0.9 \%$ & $11.6 \%$ \\
\hline Sweden & $0.9 \%$ & $1.3 \%$ & $4.2 \%$ & $0.7 \%$ & $0.9 \%$ & $2.8 \%$ & $8.9 \%$ & $6.8 \%$ & $6.1 \%$ & $16.6 \%$ & $0.8 \%$ & $0.6 \%$ & $0.3 \%$ & $1.1 \%$ & $4.0 \%$ & $2.5 \%$ \\
\hline Turkey & $0.6 \%$ & $1.5 \%$ & $3.1 \%$ & $0.8 \%$ & $0.8 \%$ & $5.9 \%$ & $1.0 \%$ & $1.0 \%$ & $9.1 \%$ & $21.2 \%$ & $0.4 \%$ & $1.3 \%$ & $0.7 \%$ & $1.0 \%$ & $11.5 \%$ & $2.9 \%$ \\
\hline South Africa & $1.3 \%$ & $0.4 \%$ & $1.3 \%$ & $29.0 \%$ & $0.7 \%$ & $3.7 \%$ & $0.2 \%$ & $28.7 \%$ & $1.9 \%$ & $6.5 \%$ & $0.5 \%$ & $1.2 \%$ & $0.3 \%$ & $0.5 \%$ & $1.7 \%$ & $4.7 \%$ \\
\hline United States & $1.2 \%$ & $0.4 \%$ & $1.5 \%$ & $2.0 \%$ & $24.3 \%$ & $11.7 \%$ & $0.3 \%$ & $0.3 \%$ & $3.0 \%$ & $5.8 \%$ & $1.4 \%$ & $1.2 \%$ & $0.9 \%$ & $1.6 \%$ & $2.2 \%$ & $11.1 \%$ \\
\hline
\end{tabular}

Source: Authors' estimates based on the IMF's Direction of Trade Statistics (2009).

Note: The table reports average trade weights for 1996-2008, which are used for constructing measures of foreign industrial production. 
Table 2. Trade Weights, continued

\begin{tabular}{|c|c|c|c|c|c|c|c|c|c|c|c|c|c|c|}
\hline & Mexico & Malaysia & Netherlands & New Zealand & Norway & Philippines & Singapore & South Africa & Spain & Sweden & Switzerland & Turkey & United Kingdom & United States \\
\hline Brazil & $3.6 \%$ & $0.4 \%$ & $5.1 \%$ & $0.1 \%$ & $0.6 \%$ & $1.1 \%$ & $1.2 \%$ & $1.1 \%$ & $3.0 \%$ & $1.4 \%$ & $1.7 \%$ & $0.5 \%$ & $3.5 \%$ & $30.6 \%$ \\
\hline China & $0.9 \%$ & $1.6 \%$ & $2.9 \%$ & $0.3 \%$ & $0.3 \%$ & $3.1 \%$ & $3.3 \%$ & $0.8 \%$ & $1.2 \%$ & $0.7 \%$ & $0.6 \%$ & $0.6 \%$ & $2.7 \%$ & $21.8 \%$ \\
\hline France & $0.4 \%$ & $0.2 \%$ & $6.9 \%$ & $0.1 \%$ & $1.2 \%$ & $0.4 \%$ & $0.9 \%$ & $0.4 \%$ & $10.1 \%$ & $1.7 \%$ & $3.6 \%$ & $1.2 \%$ & $10.1 \%$ & $8.2 \%$ \\
\hline Germany & $0.7 \%$ & $0.3 \%$ & $10.3 \%$ & $0.1 \%$ & $1.8 \%$ & $0.6 \%$ & $0.7 \%$ & $0.8 \%$ & $5.0 \%$ & $2.6 \%$ & $5.1 \%$ & $1.8 \%$ & $9.2 \%$ & $10.0 \%$ \\
\hline India & $1.1 \%$ & $2.2 \%$ & $2.1 \%$ & $0.3 \%$ & $3.4 \%$ & $3.7 \%$ & $0.6 \%$ & $18.4 \%$ & $0.7 \%$ & $0.9 \%$ & $2.9 \%$ & $0.3 \%$ & $27.4 \%$ & $1.0 \%$ \\
\hline Japan & $0.7 \%$ & $0.1 \%$ & $2.3 \%$ & $4.4 \%$ & $0.2 \%$ & $3.4 \%$ & $0.3 \%$ & $18.7 \%$ & $1.5 \%$ & $6.1 \%$ & $1.0 \%$ & $0.8 \%$ & $3.0 \%$ & $6.7 \%$ \\
\hline United Kingdom & $0.3 \%$ & $0.3 \%$ & $8.2 \%$ & $0.3 \%$ & $3.1 \%$ & $0.8 \%$ & $1.3 \%$ & $1.3 \%$ & $4.3 \%$ & $2.5 \%$ & $2.3 \%$ & $1.2 \%$ & $0.0 \%$ & $15.0 \%$ \\
\hline Australia & $0.6 \%$ & $0.8 \%$ & $1.4 \%$ & $6.1 \%$ & $0.2 \%$ & $3.6 \%$ & $5.3 \%$ & $1.3 \%$ & $0.9 \%$ & $1.1 \%$ & $1.0 \%$ & $0.3 \%$ & $5.8 \%$ & $15.6 \%$ \\
\hline Austria & $0.2 \%$ & $0.1 \%$ & $4.0 \%$ & $0.1 \%$ & $0.4 \%$ & $0.2 \%$ & $0.2 \%$ & $0.4 \%$ & $2.4 \%$ & $1.5 \%$ & $6.1 \%$ & $1.1 \%$ & $4.0 \%$ & $5.0 \%$ \\
\hline Belgium & $0.3 \%$ & $0.1 \%$ & $17.0 \%$ & $0.1 \%$ & $0.8 \%$ & $0.2 \%$ & $0.3 \%$ & $0.5 \%$ & $3.2 \%$ & $2.1 \%$ & $1.3 \%$ & $0.9 \%$ & $9.1 \%$ & $6.9 \%$ \\
\hline Canada & $2.3 \%$ & $0.2 \%$ & $0.5 \%$ & $0.1 \%$ & $0.9 \%$ & $0.4 \%$ & $0.3 \%$ & $0.2 \%$ & $0.3 \%$ & $0.3 \%$ & $0.4 \%$ & $0.1 \%$ & $2.5 \%$ & $77.2 \%$ \\
\hline Switzerland & $0.4 \%$ & $0.1 \%$ & $4.5 \%$ & $0.1 \%$ & $0.4 \%$ & $0.3 \%$ & $0.8 \%$ & $0.5 \%$ & $3.1 \%$ & $1.3 \%$ & $0.0 \%$ & $0.9 \%$ & $5.8 \%$ & $9.9 \%$ \\
\hline Denmark & $0.2 \%$ & $0.1 \%$ & $6.8 \%$ & $0.2 \%$ & $6.6 \%$ & $0.3 \%$ & $0.4 \%$ & $0.3 \%$ & $2.6 \%$ & $15.3 \%$ & $1.3 \%$ & $0.7 \%$ & $9.1 \%$ & $5.6 \%$ \\
\hline Spain & $1.6 \%$ & $0.1 \%$ & $5.6 \%$ & $0.1 \%$ & $0.8 \%$ & $0.3 \%$ & $0.3 \%$ & $0.6 \%$ & $0.0 \%$ & $1.6 \%$ & $1.7 \%$ & $1.6 \%$ & $9.4 \%$ & $5.3 \%$ \\
\hline Finland & $0.3 \%$ & $0.3 \%$ & $7.1 \%$ & $0.1 \%$ & $3.8 \%$ & $0.5 \%$ & $0.4 \%$ & $0.6 \%$ & $2.7 \%$ & $15.6 \%$ & $1.4 \%$ & $0.9 \%$ & $9.0 \%$ & $7.6 \%$ \\
\hline Hong Kong & $0.3 \%$ & $1.3 \%$ & $1.3 \%$ & $0.2 \%$ & $0.1 \%$ & $1.9 \%$ & $4.5 \%$ & $0.3 \%$ & $0.5 \%$ & $0.3 \%$ & $1.0 \%$ & $0.1 \%$ & $2.8 \%$ & $13.8 \%$ \\
\hline Indonesia & $0.3 \%$ & $1.4 \%$ & $2.7 \%$ & $0.5 \%$ & $0.1 \%$ & $5.4 \%$ & $14.5 \%$ & $0.5 \%$ & $1.4 \%$ & $0.6 \%$ & $0.5 \%$ & $0.6 \%$ & $2.2 \%$ & $13.9 \%$ \\
\hline Ireland & $0.4 \%$ & $0.4 \%$ & $5.0 \%$ & $0.1 \%$ & $1.2 \%$ & $1.0 \%$ & $1.5 \%$ & $0.4 \%$ & $2.6 \%$ & $1.3 \%$ & $2.4 \%$ & $0.4 \%$ & $29.3 \%$ & $17.6 \%$ \\
\hline Italy & $0.6 \%$ & $0.1 \%$ & $5.7 \%$ & $0.1 \%$ & $0.7 \%$ & $0.4 \%$ & $0.5 \%$ & $0.8 \%$ & $7.6 \%$ & $1.6 \%$ & $4.9 \%$ & $2.1 \%$ & $7.6 \%$ & $8.2 \%$ \\
\hline Mexico & $0.0 \%$ & $0.3 \%$ & $0.5 \%$ & $0.1 \%$ & $0.1 \%$ & $0.8 \%$ & $0.5 \%$ & $0.0 \%$ & $1.3 \%$ & $0.2 \%$ & $0.4 \%$ & $0.1 \%$ & $0.7 \%$ & $78.4 \%$ \\
\hline Malaysia & $0.6 \%$ & $0.0 \%$ & $3.0 \%$ & $0.5 \%$ & $0.1 \%$ & $2.2 \%$ & $19.1 \%$ & $0.4 \%$ & $0.4 \%$ & $0.5 \%$ & $0.7 \%$ & $0.3 \%$ & $2.6 \%$ & $20.3 \%$ \\
\hline Netherlands & $0.3 \%$ & $0.5 \%$ & $0.0 \%$ & $0.1 \%$ & $1.7 \%$ & $1.1 \%$ & $1.0 \%$ & $0.6 \%$ & $3.4 \%$ & $2.4 \%$ & $1.4 \%$ & $0.9 \%$ & $10.3 \%$ & $7.6 \%$ \\
\hline Norway & $0.1 \%$ & $0.1 \%$ & $9.0 \%$ & $0.0 \%$ & $0.0 \%$ & $0.2 \%$ & $0.6 \%$ & $0.2 \%$ & $2.3 \%$ & $11.0 \%$ & $0.8 \%$ & $0.5 \%$ & $19.5 \%$ & $7.1 \%$ \\
\hline New Zealand & $1.0 \%$ & $1.1 \%$ & $1.2 \%$ & $0.0 \%$ & $0.2 \%$ & $2.9 \%$ & $2.9 \%$ & $0.5 \%$ & $0.7 \%$ & $0.8 \%$ & $0.7 \%$ & $0.2 \%$ & $5.1 \%$ & $15.8 \%$ \\
\hline Philippines & $0.3 \%$ & $5.2 \%$ & $5.6 \%$ & $0.5 \%$ & $0.0 \%$ & $0.0 \%$ & $9.3 \%$ & $0.1 \%$ & $0.3 \%$ & $0.3 \%$ & $0.4 \%$ & $0.1 \%$ & $2.2 \%$ & $26.1 \%$ \\
\hline Singapore & $0.5 \%$ & $2.8 \%$ & $2.4 \%$ & $0.4 \%$ & $0.2 \%$ & $19.1 \%$ & $0.0 \%$ & $0.3 \%$ & $0.3 \%$ & $0.3 \%$ & $1.0 \%$ & $0.2 \%$ & $3.1 \%$ & $17.4 \%$ \\
\hline Sweden & $0.4 \%$ & $0.1 \%$ & $6.9 \%$ & $0.1 \%$ & $10.0 \%$ & $0.4 \%$ & $0.5 \%$ & $0.5 \%$ & $2.6 \%$ & $0.0 \%$ & $1.4 \%$ & $0.9 \%$ & $9.5 \%$ & $8.3 \%$ \\
\hline Turkey & $0.3 \%$ & $0.1 \%$ & $4.0 \%$ & $0.1 \%$ & $0.6 \%$ & $0.8 \%$ & $0.5 \%$ & $1.2 \%$ & $5.0 \%$ & $1.9 \%$ & $3.8 \%$ & $0.0 \%$ & $9.0 \%$ & $10.0 \%$ \\
\hline South Africa & $0.2 \%$ & $0.1 \%$ & $1.8 \%$ & $0.1 \%$ & $0.1 \%$ & $0.6 \%$ & $0.5 \%$ & $0.0 \%$ & $1.5 \%$ & $0.6 \%$ & $1.0 \%$ & $0.3 \%$ & $4.5 \%$ & $5.9 \%$ \\
\hline United States & $14.2 \%$ & $1.0 \%$ & $2.1 \%$ & $0.3 \%$ & $0.4 \%$ & $2.1 \%$ & $2.1 \%$ & $0.5 \%$ & $0.8 \%$ & $0.8 \%$ & $1.3 \%$ & $0.5 \%$ & $4.8 \%$ & $0.0 \%$ \\
\hline
\end{tabular}

Note: The table reports average trade weights for 1996-2008, which are used for constructing measures of foreign industrial production. 


\section{REFERENCES}

Adrian, T. and H. S. Shin, 2008, "Liquidity, Monetary Policy, and Financial Cycles," Current Issues in Economics and Finance, Federal Reserve Bank of New York, 08-January.

Berger, A. and C. Bouwman, 2009, "Bank Liquidity Creation," Review of Financial Studies, Oxford University Press for Society for Financial Studies, Vol. 22, No. 9 (September), pp. 3779-837.

Bernanke, B. and M. Gertler, 1995, "Inside the Black Box: The Credit Channel of Monetary Policy Transmission," Journal of Economic Perspectives, Vol. 9, pp. 27-48.

and S. Gilchrist, 1999, "The Financial Accelerator in a Quantitative Business Cycle Framework," Handbook of Macroeconomics, Vol. 1C, pp. 1341-93 (Amsterdam: North-Holland).

Bernanke, B., C. Lown, and B. Friedman, 1991, "The Credit Crunch," Brookings Papers on Economic Activity: 2, pp. 205-47, Brookings Institution.

Binder, M., Q. Chen, and X. Zhang, 2009, “On the Effects of Monetary Policy Shocks on Exchange Rates," Working Paper (Goethe University Frankfurt).

Carlson, M., T. King, and K. Lewis, 2008, "Distress in the Financial Sector and Economic Activity," Finance and Economics Discussion Series 2008-48 (Federal Reserve Board, Washington, D.C.).

Dees, S., F. Di Mauro, Filippo, M. H. Pesaran, and V. Smith, 2007, "Exploring the International Linkages of the Euro Area: A Global VAR Analysis," Journal of Applied Econometrics, No. 22, pp. 1-38.

Gilchrist, S., V. Yankov, and E. Zakrajsek, 2009, "Credit market shocks and economic fluctuations: Evidence from corporate bond and stock markets," Journal of Monetary Economics, Vol. 56, pp. 471-93.

Galesi, A. and S. Sgherri, 2009, "Regional Financial Spillovers Across Europe: A Global VAR Analysis," IMF Working Paper No. 09/23, (Washington: International Monetary Fund).

Gray, D. and S. Malone, 2008, Macrofinancial Risk Analysis (United Kingdom: Wiley Finance).

Gray, D., R. Merton, and Z. Bodie, 2008, "New Framework for Measuring and Managing Macrofinancial Risk and Financial Stability," Harvard Business School Working Paper No. 09-015.

Jacobson, T., J. Linde, and K. Roszbach, 2005, "Exploring interactions between real activity and the financial stance," Journal of Financial Stability, Vol. 1, pp. 308-41. 
Kamil, H., and K. Rai, forthcoming, "The Global Credit Crunch and Foreign Banks' Lending to Emerging Markets: Why Did Latin America Fare Better?" IMF Working Paper (Washington: International Monetary Fund).

Kashyap, A. and J. Stein, 1995, "The Impact of Monetary Policy on Bank Balance Sheets,“ Carnegie-Rochester Conference Series on Public Policy, Vol. 42, pp. 151-95.

Kiyotaki, N. and J. Moore, 1997, “Credit Cycles," Journal of Political Economy, Vol. 105, pp. $211-48$.

KMV, 2001, “Modeling Default Risk," KMV Corp.

Lane, P., and J. Shambaugh, 2010, "Financial Exchange Rates and International Currency Exposures," American Economic Review, Vol. 100, No. 1 (March ), pp. 518-40.

Marcucci, J. and M. Quagliariello, 2008, "Is bank portfolio riskiness procyclical? Evidence from Italy using a vector autoregression," Journal of International Financial Markets, Institutions, and Money, Vol. 18, pp. 46-63.

Merton, R.C., 1973, “Theory of Rational Option Pricing,” Bell Journal of Economics_and Management Science, 4 (Spring): pp. 141-83.

— 1974, "On the Pricing of Corporate Debt: The Risk Structure of Interest Rates." Journal of Finance 29 (May), pp. 449-70.

MKMV, 2003, “Modeling Default Risk,” Moody’s-KMV Corporation, www.mkmv.com.

Pesaran, M.H., T. Schuermann, and S.M. Weiner, 2004, "Modelling Regional Interdependencies Using a Global Error Correcting Macroeconometric Model," Journal of Business and Economic Statistics, 22, pp. 129-62.

Vassalou, M. and Y. Xing, 2004, “Default Risk in Equity Returns," Journal of Finance, Vol. 59, pp. 831-68. 


\section{APPENDIX I. DATA DESCRIPTION}

Appendix I Table 1. Definitions and Sources

\begin{tabular}{|c|c|c|c|}
\hline Variable & Description & Source & Notes \\
\hline edfb & $\begin{array}{l}\text { Asset weighted one } \\
\text { year ahead expected } \\
\text { default probability of } \\
\text { financial firms }\end{array}$ & Moody's KMV & $\begin{array}{l}\text { Data for China from March } 1996 \\
\text { to April } 1997 \text { are not available, } \\
\text { and are interpolated in a linear } \\
\text { manner. }\end{array}$ \\
\hline edfn & $\begin{array}{l}\text { Asset weighted one } \\
\text { year ahead expected } \\
\text { default probability of } \\
\text { nonfinancial firms }\end{array}$ & Moody's KMV & $\begin{array}{l}\text { Missing data for October } 1996 \\
\text { are interpolated. }\end{array}$ \\
\hline$y$ & $\begin{array}{l}\text { Logarithm of industrial } \\
\text { production index }\end{array}$ & $\begin{array}{l}\text { GDS for Australia } \\
\text { and New Zealand; } \\
\text { CEIC for Brazil, } \\
\text { China, Hong Kong } \\
\text { SAR, Indonesia, } \\
\text { Malaysia, Philippines, } \\
\text { Singapore and South } \\
\text { Africa; } \\
\text { IFS for all other } \\
\text { economies. }\end{array}$ & $\begin{array}{l}\text { Data for China is the value } \\
\text { added of industry, which to our } \\
\text { knowledge the closest available } \\
\text { measure of the industrial } \\
\text { production. The series is spliced } \\
\text { with the implied value from the } \\
\text { year on year growth value from } \\
1995 \text { January onwards. } \\
\text { All data from CEIC and for India } \\
\text { are available in seasonally } \\
\text { unadjusted form and adjusted } \\
\text { using Census X12 in EViews. }\end{array}$ \\
\hline$r$ & $\begin{array}{l}\text { Money market rate } \\
\text { deflated by consumer } \\
\text { price index (CPI) }\end{array}$ & $\begin{array}{l}\text { Money market rates } \\
\text { are from IFS and } \\
\text { CEIC. } \\
\text { Consumer price } \\
\text { indices for Australia } \\
\text { and New Zealand are } \\
\text { from GDS, while the } \\
\text { rest economies are } \\
\text { from IFS. } \\
\text { The } 7 \text { day weighted } \\
\text { average CHIBOR is } \\
\text { used for China. }\end{array}$ & $\begin{array}{l}\text { Data for Sweden from } \\
\text { December } 2004 \text { onwards are } \\
\text { not available in the IFS, and the } \\
\text { policy-related interest rate from } \\
\text { the GDS is taken instead. } \\
\text { Missing data for September } \\
1992 \text { is interpolated. }\end{array}$ \\
\hline$p^{s}$ & $\begin{array}{l}\text { Logarithm of share } \\
\text { price index deflated by } \\
\mathrm{CPI}\end{array}$ & IFS & \\
\hline$q$ & $\begin{array}{l}\text { Logarithm of real } \\
\text { effective exchange } \\
\text { rate }\end{array}$ & $\begin{array}{l}\text { Data for Hong Kong } \\
\text { SAR, Indonesia, } \\
\text { Mexico and Turkey } \\
\text { are from CEIC, while } \\
\text { the rest are from IFS. }\end{array}$ & \\
\hline$p^{o}$ & $\begin{array}{l}\text { Logarithm of world } \\
\text { spot petroleum price }\end{array}$ & IFS & \\
\hline
\end{tabular}




\begin{tabular}{|c|c|c|}
\hline Appendix I & 2. Number & \\
\hline Country & Corporates & Banks \\
\hline Australia & 1542 & 8 \\
\hline Austria & 65 & 6 \\
\hline Belgium & 105 & 2 \\
\hline Brazil & 257 & 26 \\
\hline Canada & 1218 & 9 \\
\hline China & 1913 & 14 \\
\hline Denmark & 118 & 37 \\
\hline Finland & 113 & 3 \\
\hline France & 605 & 22 \\
\hline Germany & 631 & 14 \\
\hline Hong Kong & 793 & 9 \\
\hline India & 1980 & 39 \\
\hline Indonesia & 269 & 26 \\
\hline Ireland & 57 & 2 \\
\hline Italy & 229 & 23 \\
\hline Japan & 3436 & 95 \\
\hline Malaysia & 816 & 9 \\
\hline Mexico & 90 & 3 \\
\hline Netherlands & 123 & 3 \\
\hline New Zealand & 110 & n.a. \\
\hline Norway & 168 & 22 \\
\hline Philippines & 137 & 16 \\
\hline Singapore & 548 & 3 \\
\hline South Africa & 268 & 9 \\
\hline Spain & 106 & 8 \\
\hline Sweden & 366 & 6 \\
\hline Switzerland & 185 & 26 \\
\hline Turkey & 186 & 16 \\
\hline United Kingdom & 1333 & 10 \\
\hline United States & 4367 & 443 \\
\hline Average & 738 & 31 \\
\hline Advanced & 858 & 36 \\
\hline Emerging & 458 & 20 \\
\hline Total & 22134 & 909 \\
\hline Advanced & 18013 & 728 \\
\hline Emerging & 4121 & 181 \\
\hline
\end{tabular}




\begin{tabular}{|c|c|c|c|c|c|c|c|c|c|c|}
\hline \multicolumn{11}{|c|}{ Appendix I Table 3. Descriptive Statistics } \\
\hline & Mean & Median & Std. Dev. & Skewness & Kurtosis & Mean & Median & Std. Dev. & Skewness & Kurtosis \\
\hline & \multicolumn{5}{|c|}{ Expected Default Frequency of Banks } & \multicolumn{5}{|c|}{ Expected Default Frequency of Banks } \\
\hline Australia & 0.004 & 0.000 & 0.047 & 0.634 & 27.965 & 0.012 & -0.004 & 0.180 & 1.777 & 26.685 \\
\hline Austria & 0.006 & -0.001 & 0.358 & 0.759 & 72.291 & 0.013 & -0.004 & 0.499 & 0.139 & 66.508 \\
\hline Belgium & 0.013 & 0.000 & 0.111 & 10.569 & 122.022 & 0.001 & -0.004 & 0.090 & 0.517 & 14.699 \\
\hline Brazil & -0.003 & -0.015 & 0.807 & -0.103 & 32.637 & -0.021 & -0.046 & 0.691 & 1.245 & 9.891 \\
\hline Canada & 0.001 & -0.003 & 0.076 & 0.213 & 41.514 & 0.012 & -0.007 & 0.146 & 1.293 & 7.663 \\
\hline Switzerland & 0.002 & -0.001 & 0.156 & -3.061 & 34.851 & 0.000 & -0.001 & 0.112 & -0.032 & 19.470 \\
\hline China & -0.004 & -0.001 & 0.427 & 2.647 & 26.301 & 0.001 & 0.000 & 0.639 & 1.982 & 18.223 \\
\hline Denmark & 0.008 & 0.000 & 0.147 & 0.765 & 51.681 & 0.002 & -0.001 & 0.048 & -0.131 & 6.254 \\
\hline Finland & -0.045 & -0.006 & 0.502 & -9.023 & 101.920 & 0.002 & -0.001 & 0.082 & -2.790 & 36.956 \\
\hline France & 0.001 & -0.001 & 0.072 & 0.659 & 41.124 & 0.004 & -0.003 & 0.280 & 0.415 & $35.72 \varepsilon$ \\
\hline Germany & 0.011 & -0.002 & 0.187 & 1.400 & 21.546 & 0.002 & -0.004 & 0.150 & 0.640 & 36.892 \\
\hline Hong Kong SAR & 0.005 & -0.004 & 0.342 & 2.672 & 40.569 & 0.008 & -0.004 & 0.194 & 0.778 & 6.570 \\
\hline India & 0.014 & -0.013 & 0.205 & 1.239 & 7.528 & 0.016 & -0.015 & 0.337 & 0.838 & 6.114 \\
\hline Indonesia & 0.000 & -0.009 & 1.110 & -0.598 & 8.524 & 0.016 & -0.002 & 0.799 & 0.042 & 7.885 \\
\hline Ireland & 0.025 & -0.002 & 0.212 & 8.391 & 89.490 & 0.018 & -0.001 & 0.232 & 2.461 & 19.474 \\
\hline Italy & 0.001 & -0.001 & 0.048 & 0.747 & 13.713 & 0.003 & -0.003 & 0.126 & 1.714 & 14.966 \\
\hline Japan & 0.033 & 0.008 & 0.317 & 2.129 & 25.252 & 0.013 & 0.010 & 0.203 & -0.189 & $6.06 s$ \\
\hline Malaysia & 0.000 & -0.019 & 0.623 & -0.425 & 9.730 & 0.012 & -0.007 & 0.674 & -0.557 & 12.190 \\
\hline Mexico & -0.013 & -0.032 & 3.212 & 0.224 & 18.646 & 0.000 & -0.010 & 0.181 & 0.827 & 7.662 \\
\hline Netherlands & 0.002 & -0.001 & 0.032 & 1.988 & 18.363 & 0.004 & -0.002 & 0.152 & -0.397 & 11.273 \\
\hline New Zealand & 0.010 & -0.004 & 0.474 & 0.613 & 34.884 & 0.003 & -0.001 & 0.187 & 2.145 & 34.805 \\
\hline Norway & 0.007 & -0.003 & 0.305 & 1.243 & 73.579 & 0.009 & -0.002 & 0.156 & 0.654 & 14.815 \\
\hline Philippines & 0.014 & -0.008 & 0.488 & -0.125 & 12.639 & 0.027 & 0.008 & 0.457 & -0.201 & 4.978 \\
\hline Singapore & 0.001 & -0.002 & 0.227 & -1.773 & 34.035 & 0.015 & 0.000 & 0.317 & 0.030 & 14.415 \\
\hline South Africa & 0.002 & -0.001 & 0.118 & -0.106 & 13.017 & 0.002 & -0.004 & 0.247 & -0.463 & 20.534 \\
\hline Spain & 0.001 & 0.000 & 0.017 & 1.799 & 10.740 & 0.002 & -0.002 & 0.068 & -0.695 & 31.807 \\
\hline Sweden & 0.000 & -0.003 & 0.401 & 0.040 & 73.277 & 0.003 & -0.002 & 0.177 & 0.074 & $23.87 \mathrm{C}$ \\
\hline Turkey & 0.014 & -0.039 & 0.588 & 0.103 & 10.648 & 0.016 & -0.011 & 0.413 & 0.424 & 6.696 \\
\hline United Kingdom & 0.005 & -0.004 & 0.069 & 0.591 & 17.728 & 0.004 & -0.003 & 0.064 & 0.585 & 9.937 \\
\hline United States & 0.026 & 0.001 & 0.148 & 4.795 & 31.579 & 0.009 & 0.000 & 0.121 & 0.399 & 8.268 \\
\hline
\end{tabular}

Source: Authors' estimates.

Note: All series, except interest rates, are monthly percent changes. Interest rates are monthly differences, in percentage points. 
Appendix I Table 3. Descriptive Statistics, continued

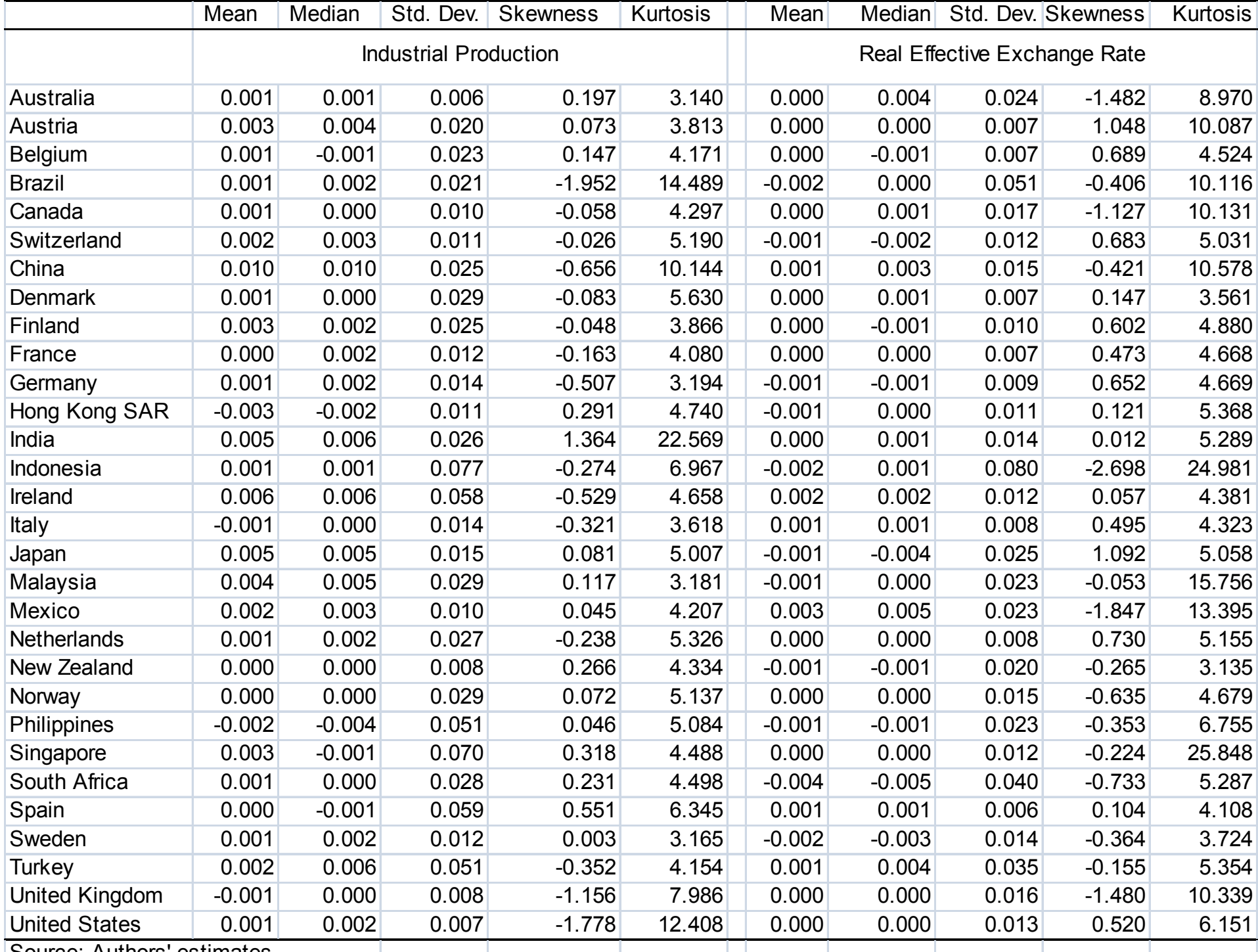

Source: Authors' estimates.

Note: All series, except interest rates, are monthly percent changes. Interest rates are monthly differences, in percentage points. 
Appendix I Table 3. Descriptive Statistics, continued

\begin{tabular}{|c|c|c|c|c|c|c|c|c|c|c|}
\hline \multirow{3}{*}{ Australia } & \multirow[t]{2}{*}{ Mean } & Median & Std. Dev. & Skewness & \multirow[t]{2}{*}{ Kurtosis } & \multirow[t]{2}{*}{ Mean } & Median & \multicolumn{2}{|c|}{ Std. Dev. Skewness } & \multirow[t]{2}{*}{ Kurtosis } \\
\hline & & \multicolumn{3}{|c|}{ Real Short-Term Interest Rate } & & & \multicolumn{3}{|c|}{ Real Stock Prices } & \\
\hline & -0.016 & 0.013 & 0.416 & 0.245 & 10.162 & 0.001 & 0.010 & 0.037 & -1.170 & 4.679 \\
\hline Austria & -0.006 & -0.010 & 0.319 & -0.195 & 3.832 & 0.007 & 0.013 & 0.065 & 0.246 & 10.487 \\
\hline Belgium & -0.016 & -0.009 & 0.372 & -0.128 & 3.207 & 0.000 & 0.008 & 0.050 & -1.749 & 10.214 \\
\hline Brazil & -0.056 & -0.087 & 2.788 & 3.693 & 31.134 & 0.008 & 0.018 & 0.099 & -1.287 & 7.003 \\
\hline Canada & -0.023 & -0.045 & 0.491 & 0.179 & 3.746 & 0.003 & 0.011 & 0.049 & -1.332 & 6.615 \\
\hline Switzerland & -0.007 & -0.011 & 0.386 & 0.185 & 3.088 & 0.003 & 0.012 & 0.049 & -0.942 & 4.773 \\
\hline China & -0.020 & 0.050 & 0.812 & -0.190 & 3.722 & 0.006 & 0.001 & 0.082 & 0.210 & 4.091 \\
\hline Denmark & -0.004 & -0.004 & 0.320 & 0.063 & 2.849 & 0.003 & 0.013 & 0.048 & -1.629 & 8.689 \\
\hline Finland & -0.029 & -0.050 & 0.327 & -0.737 & 5.629 & 0.003 & 0.021 & 0.084 & -0.734 & 5.251 \\
\hline France & -0.009 & -0.002 & 0.294 & -0.043 & 3.384 & 0.002 & 0.011 & 0.058 & -0.657 & 3.677 \\
\hline Germany & -0.008 & -0.007 & 0.305 & 0.103 & 3.087 & 0.001 & 0.010 & 0.064 & -0.961 & 5.322 \\
\hline Hong Kong SAR & -0.005 & 0.009 & 1.562 & -0.125 & 37.051 & 0.002 & 0.007 & 0.070 & -0.509 & 4.393 \\
\hline India & -0.063 & -0.001 & 8.753 & 1.562 & 45.611 & 0.003 & 0.014 & 0.070 & -0.451 & 2.982 \\
\hline Indonesia & -0.044 & 0.052 & 6.459 & 1.696 & 26.268 & -0.004 & 0.005 & 0.098 & -1.147 & 6.464 \\
\hline Ireland & -0.009 & 0.008 & 0.396 & -0.284 & 3.878 & -0.002 & 0.009 & 0.061 & -1.049 & 4.869 \\
\hline Italy & -0.025 & -0.010 & 0.224 & -0.368 & 3.293 & 0.001 & 0.009 & 0.054 & -0.668 & 5.599 \\
\hline Japan & -0.007 & -0.001 & 0.333 & 0.617 & 10.827 & -0.004 & -0.004 & 0.049 & -0.679 & 5.730 \\
\hline Malaysia & -0.028 & 0.007 & 0.900 & -1.140 & 16.611 & -0.003 & 0.002 & 0.067 & -0.058 & 5.317 \\
\hline Mexico & 0.018 & 0.035 & 2.144 & 2.354 & 23.300 & 0.006 & 0.016 & 0.074 & -1.029 & 6.080 \\
\hline Netherlands & -0.008 & 0.012 & 0.271 & -0.439 & 4.609 & -0.001 & 0.009 & 0.058 & -1.425 & 8.059 \\
\hline New Zealand & -0.019 & 0.003 & 0.401 & -1.159 & 8.431 & 0.003 & 0.008 & 0.134 & -0.917 & 34.713 \\
\hline Norway & -0.009 & -0.023 & 0.604 & -0.571 & 7.499 & 0.004 & 0.016 & 0.061 & -1.606 & 8.072 \\
\hline Philippines & -0.039 & -0.078 & 2.535 & 0.343 & 34.022 & 0.010 & 0.001 & 0.230 & 0.659 & 9.526 \\
\hline Singapore & -0.032 & -0.034 & 0.710 & 0.187 & 11.996 & -0.002 & 0.009 & 0.075 & -0.461 & 5.279 \\
\hline South Africa & -0.035 & -0.078 & 0.744 & 1.042 & 8.851 & 0.002 & 0.012 & 0.056 & -1.097 & 5.103 \\
\hline Spain & -0.026 & -0.003 & 0.324 & -0.323 & 4.027 & 0.005 & 0.007 & 0.058 & -0.704 & 4.576 \\
\hline Sweden & -0.037 & -0.020 & 0.377 & 0.401 & 4.679 & 0.004 & 0.012 & 0.064 & -0.681 & 3.773 \\
\hline Turkey & -0.158 & -0.075 & 41.747 & 1.016 & 60.209 & 0.001 & 0.004 & 0.116 & -0.155 & 4.480 \\
\hline United Kingdom & -0.014 & 0.002 & 0.586 & 0.069 & 9.505 & 0.002 & 0.005 & 0.039 & -0.780 & 3.811 \\
\hline United States & -0.019 & -0.026 & 0.444 & 0.868 & 6.494 & 0.001 & 0.004 & 0.039 & -1.020 & 5.883 \\
\hline
\end{tabular}

Source: Authors' estimates.

Note: All series, except interest rates, are monthly percent changes. Interest rates are monthly differences, in percentage points. 


\section{Appendix II. Contingent Claims Analysis and Estimating Default Probabilities FOR CORPORATES AND BANKS}

The contingent claims analysis (CCA) is based on the Merton Model and it provides a methodology to combine balance sheet information with widely used finance and risk management tools to construct marked-to-market balance sheets that better reflect underlying risk (see Merton 1973, 1974 and Gray, Merton, and Bodie 2008). It can be used to derive a set of risk indicators for individual firms, financial institutions that can serve as risk indicators and barometers of vulnerability and calculate default probabilities. An estimate of the market value of assets and asset volatility is needed, but market value of assets is not directly observable because many of the assets on the balance sheet of a financial institution are not traded. CCA imputes the value and volatility of assets indirectly using the market value of equity from stock price data, equity volatility (from equity data and/or equity options), and the book value of short- and long-term obligations. This is then used to calculate risk indicators such as the probability of default, credit spreads, or other risk indicators.

The value of assets of a corporate or bank at time $\mathrm{t}$ is $A(t)$. Assets are uncertain (stochastic), and the evolution of the asset is given by $d A / A=\mu_{A} d t+\sigma_{A} \varepsilon \sqrt{t}$, where $\mu_{A}$ is the drift rate or asset return, $\sigma_{A}$ is equal to the standard deviation of the asset return, and $\varepsilon$ is normally distributed, with zero mean and unit variance. The probability distribution of the asset at time $\mathrm{T}$ is shown below in (a)

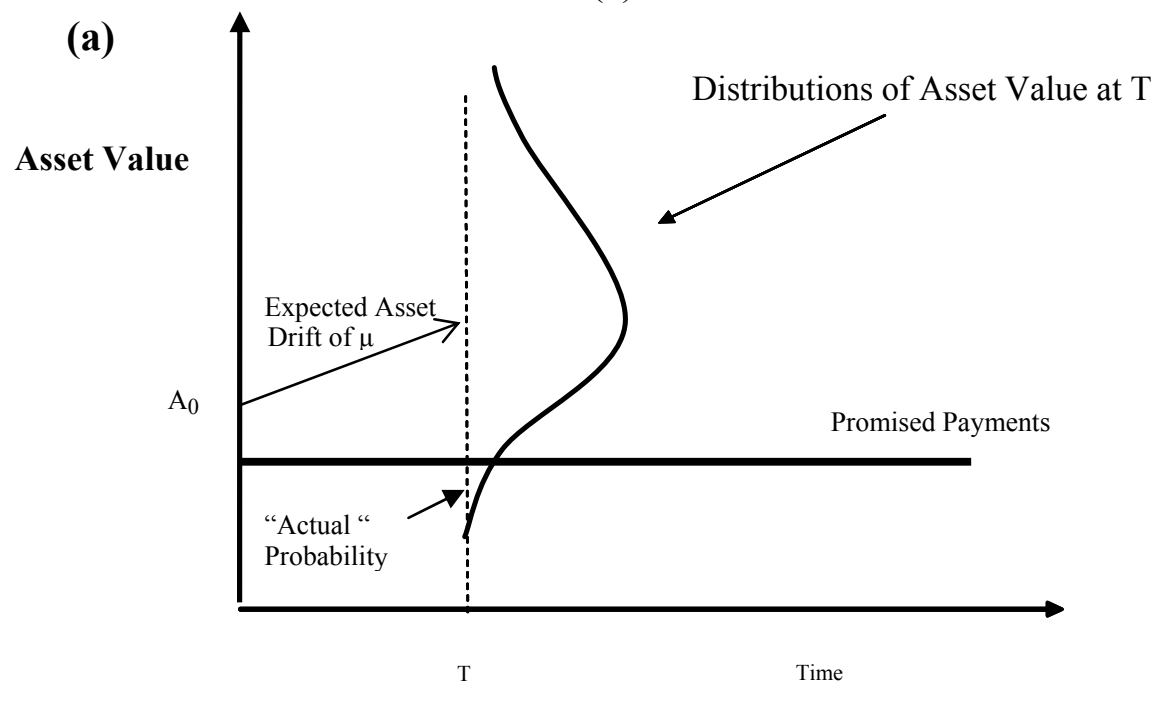

Default occurs when assets fall to or below the promised payments on debt which define the default barreir, $B_{t}$. The probability of default is the probability that $A_{t} \leq B_{t}$ which is:

$\operatorname{Prob}\left(A_{t} \leq B_{t}\right)=\operatorname{Prob}\left(A_{0} \exp \left[\left(\mu_{A}-\sigma_{A}^{2} / 2\right) t+\sigma_{A} \varepsilon \sqrt{t}\right] \leq B_{t}\right)=\operatorname{Prob}\left(\varepsilon \leq-d_{2, \mu}\right)$ 
Since $\varepsilon \square N(0,1)$, the "actual" probability of default is $N\left(-d_{2, \mu}\right)$, where

$d_{2, \mu}=\frac{\ln \left(A_{0} / B_{t}\right)+\left(\mu_{A}-\sigma_{A}^{2} / 2\right) t}{\sigma_{A} \sqrt{t}}$, this term is called the distance to default. $N(\square)$ is the cumulative standard normal distribution.

Merton Model. We can use this basic idea to construct risk-adjusted balance sheets, i.e. CCA balance sheets where the total market value of assets, $A$, at any time, $t$, is equal to the sum of its equity market value, $E$, and its risky debt, $D$, maturing at time $T$. The asset value is stochastic and may fall below the value of outstanding liabilities. Equity and debt derive their value from the uncertain assets. As pointed out by Merton (1973) equity value is the value of an implicit call option on the assets, with an exercise price equal to default barrier, $B$. The value of risky debt is equal to default-free debt minus the present value of expected loss due to default. The firm's outstanding liabilities constitute the bankruptcy level. The expected potential loss due to default can be calculated as the value of a put option on the assets, A, with an exercise price equal to $B, \mathrm{t}$ is the time horizon, $\mathrm{r}$ is the risk free rate, and $\sigma_{A}$, asset volatility.

$$
\begin{aligned}
& \text { Risky Debt }=\text { Default-free Debt }- \text { Potential Loss due to Default } \\
& \qquad D(t)=B e^{-r T}-P_{E}(t) \\
& d_{1}=\frac{\ln \left(\frac{A}{B}\right)+\left(r+\frac{\sigma_{A}^{2}}{2}\right) T}{\sigma_{A} \sqrt{T}} \text { and } d_{2}=\frac{\ln \left(\frac{A}{B}\right)+\left(r-\frac{\sigma_{A}^{2}}{2}\right) T}{\sigma_{A} \sqrt{T}}
\end{aligned}
$$

The calibration of the model uses the value of equity, the volatility of equity, the distress barrier as inputs into two equations in order to calculate the implied asset value and implied asset volatility. ${ }^{2}$ Equity and equity volatility are consensus forecasts of market participants and this provide forward-looking information. The value of assets is unobservable, but it can be implied using CCA. In the Merton Model for firms, banks and non-bank financials with traded equity use equity, $E$, and equity volatility, $\sigma_{E}$, and the distress barrier in the following two equations to solve for the two unknowns $\mathrm{A}$, asset value, and $\sigma_{A}$, asset volatility.

$$
\begin{gathered}
E=A_{0} \mathrm{~N}\left(d_{1}\right)-B e^{-r T} \mathrm{~N}\left(d_{2}\right) \\
E \sigma_{E}=A \sigma_{A} N\left(d_{1}\right)
\end{gathered}
$$

Now we have all the parameters which can be used to estimate credit risk indicators. The present value of expected losses associated with outstanding liabilities can be valued as an implicit put option. This implicit put option is calculated with the default threshold as strike price on the current asset value of each institution. Thus, the present value of expected loss can be computed as

$$
P_{E}=B e^{-r T} N\left(-d_{2}\right)-A_{0} N\left(-d_{1}\right)
$$

\footnotetext{
${ }^{2}$ See Merton (1973 and 1974), Gray, Merton, and Bodie (2008), and Gray and Malone (2008).
} 
Once the asset value, asset volatility are known, together with the default barrier, time horizon, and $\mathrm{r}$, the values of the implicit put option, $P_{E}(t)$, can be calculated. Note that by rearranging the formula for $P_{E}(t)$ we distinguish between default probability and loss given default (LGD), such that

$$
P_{E}=N\left(-d_{2}\right) \underbrace{\left(1-\frac{N\left(-d_{1}\right)}{N\left(-d_{2}\right)} \frac{A}{B e^{-r T}}\right)}_{L G D} B e^{-r T}
$$

Shown in (b) below is the probability distribution (dashed line) with drift of the risk-free interest rate, r. Risk adjusted (or risk-neutral) probability of default is $N\left(-d_{2}\right)$, where $d_{2}=\frac{\ln \left(A_{0} / B_{t}\right)+\left(r-\sigma_{A}^{2} / 2\right) t}{\sigma_{A} \sqrt{t}}$. The actual probability of default from (a) is shown too.

(b)
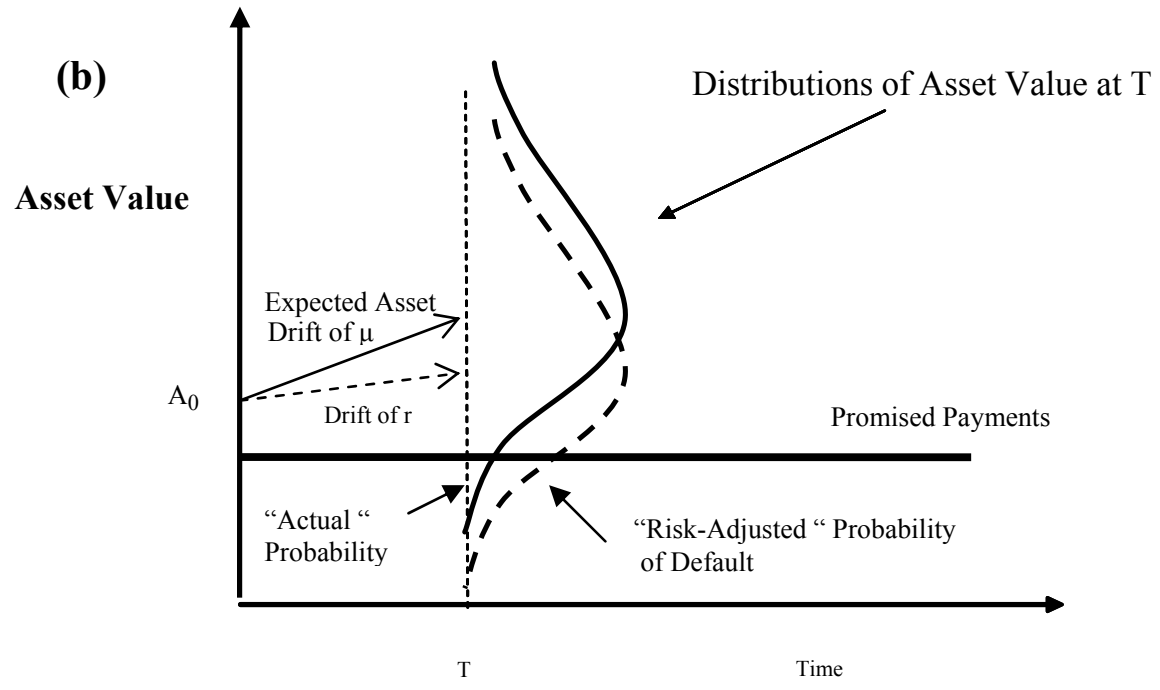

Moody's KMV Model. In the 1990s a company called KMV adapted Merton's approach for commercial applications. They used information from the equity market for firms, along with book value information of liabilities to get estimates of distance-to-distress, which were used with a large database of actual defaults to estimate Expected Default Probabilities (EDFTM). KMV was purchased by Moody's in 2002 and is now Moody's-KMV, or MKMV, for short. The exact methodology is confidential, but general descriptions can be found on the MKMV website (www.mkmv.com), and in KMV (2001) and MKMV (2003). MKMV's EDF credit measure is calculated using an iterative proceedure to solve for the asset volatility. It uses and initial guess of volatility to determine asset value and de-lever the equity returns (according to MKMV 2003). The volatility of the asset returns are used as an input into the next iteration of asset values and asset returns until a convergence is obtained. In essence, the model used equity return volatility, equity values, distress barrier from book value of liabilities, and time horizon to get a distance-to-distress. This distance-to-distress was then mapped to actual default probabilities, called expected default probabilities (EDFs), using a database of detailed real world default probabilities for many firms. The distance-to-distress and the CEDF are calculated as follows: 


$$
\begin{gathered}
D D_{K M V}=f\left(\frac{\ln \left(A_{0} / B_{t}\right)+\left(\mu_{A}-\sigma_{A}^{2} / 2\right) t}{\sigma_{A} \sqrt{t}}\right) \\
E D F_{t}=f\left(D D_{K M V}(t)\right)
\end{gathered}
$$

MKMV estimates the "actual" default probabilities. The EDF credit measure is calculated daily for 35,000 corporations and financial institutions in 55 countries (see MKMV 2001 and 2003). Robustness checks confirm that the model to be quite accurate and is a leading indicator for default. MKMV lead actual defaults, for example high yield default forecasts, according to MKMV EDFs, lead actual default rates by about a year.

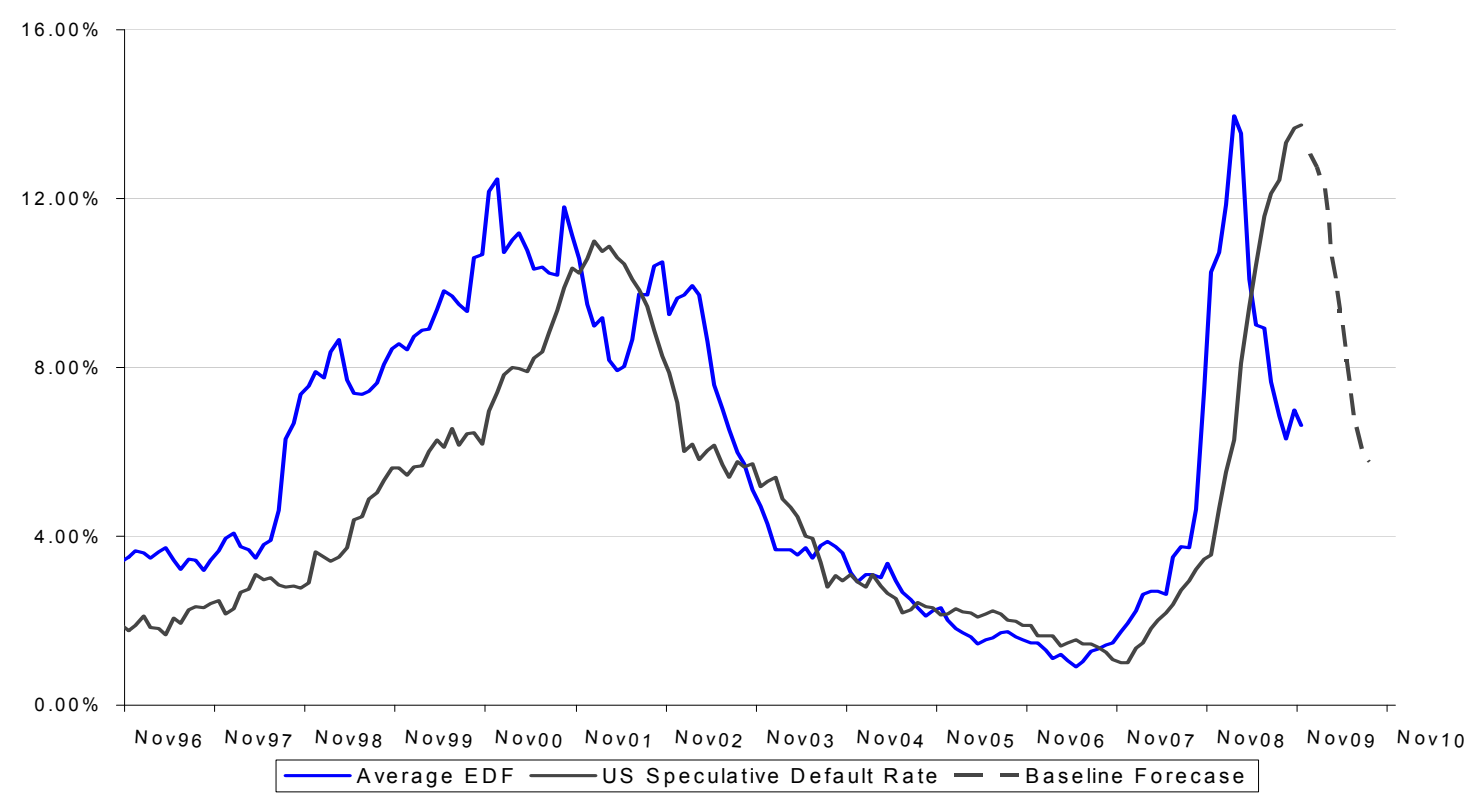

Source: MKMV

For sectors (groups of firms or banks) the time series of median ( $50^{\text {th }}$ percentile) EDFs for corporate sectors and banking sectors is one candidate for a sector credit risk measure, but this would be biased by small firms in the sample. To get a single aggregate measure which is linked to the size of the firms and size of default risk in the sector, the EDFs are weighted by the market value of assets of the firms and banks in the sector for the analysis in this paper. Extensions and more details of CCA models can be found in Gray and Malone (2008). 